\title{
O PRINCÍPIO DA PUBLICIDADE NO PROCESSO PENAL, LIBERDADE DE IMPRENSA E A TELEVISÃO: UMA ANÁLISE TRANSDISCIPLINAR
}

\author{
Bernardo Montalvão Varjão de Azevedo, \\ Mestrando em Direito Público na linha de \\ Limites à Validade do Discurso Jurídico \\ junto à Faculdade de Direito da \\ Universidade Federal da Bahia. Pós- \\ Graduado em Ciências Criminais junto à \\ Fundação Faculdade de Direito vinculada \\ ao Programa de Pós-Graduação da \\ Universidade Federal da Bahia. Professor de \\ Direito Penal e Processo penal da \\ Universidade Católica do Salvador, \\ Professor de Direito Penal da Universidade \\ Salvador - UNIFACS. Analista Previdenciário \\ do INSS-BA junto à Procuradoria Federal \\ Especializada.
}

RESUMO: A publicidade é valor caro à democracia. A publicidade é redimensionada na sociedade pós-moderna contemporânea. A publicidade cria uma realidade virtual mais real do que a real. A publicidade invade os lares e redesenha, através da tecnologia, a sociedade fluida, heterogênea, complexa, paradoxal e consumerista atual. A publicidade é amplificada pelas ondas do rádio, artificializada por meio dos sinais da televisão e "globalizada" através da internet, a qual insere o homem no "ciberespaço", cria a aparência de inclusão para o excluído; constrói, destrói e reconstrói o significado de democracia; transforma o homem em produto descartável.

ABSTRACT: Publicity is a expensive value to democracy. Advertising is scaled in the contemporary post-modern society. Advertising creates a virtual reality more real than the real one. Advertising invades homes and designs in different ways, through technology, the fluid, heterogeneous, complex, contradictory and consumption actual society. Advertising is amplified by the radio waves, artificalized by signals of 
television and globalized through the internet, which puts man in "cyberspace", creates the appearance of inclusion to the excluded; constructs, destroys and reconstructs the meaning of democracy; transforms man in disposable product.

PALAVRAS-CHAVE: 1. Princípio da Publicidade; 2. Liberdade de Imprensa; 3. Processo Penal; 4. Análise Transdiciplinar; 5. Sociedade Contemporânea.

KEYWORDS: 1. Principle of Publicity, 2. Freedom of the Press, 3. Criminal Procedure, 4. Transdiciplinar Analysis 5. Contemporary Society.

SUMÁRIO: 1. Introdução; 1.1. O princípio da publicidade e sua relação com a liberdade de imprensa; 2 . O princípio da publicidade na sociedade contemporânea: uma análise transdiciplinar; 2.1. O princípio da publicidade e o mal-estar da modernidade; 2.2. O princípio da publicidade e o mal-estar na pós-modernidade; 2.3. O princípio da publicidade e a televisão; 2.4. O princípio da publicidade e a sensação de insegurança; 3. Conclusão.

\section{INTRODUÇÃO}

Estudar o princípio constitucional da publicidade nos dias atuais não é tarefa fácil. Isto porque tal princípio, concebido como norma ${ }^{1}$, foi e continua a ser alvo de um intenso e açodado processo de transformação social e de inovações tecnológicas. A intensidade e celeridade desse processo, que provoca nas pessoas a impressão de que, nunca antes na história da humanidade, a sociedade "evoluiu" tão rápido e em tão pouco tempo, é que recomenda um novo olhar acerca do princípio da publicidade. Afinal, desde a promulgação da Constituição, em 1988, quando esta dedicou o inciso LX do artigo $5^{\circ 3}$ para tratar da matéria, já se passaram quase vinte anos até os dias de hoje. E não é demasiado asseverar que, nesses últimos vinte anos, o mundo experimentou mais inovações tecnológicas do que durante todo o século XIX . 
Nos últimos vinte anos, o homem descobriu a telefonia móvel, criou e incrementou a internet, aprimorou a comunicação via satélite, aperfeiçoou a transmissão de dados por meio de cabos de fibra ótica e transformou a televisão em utensílio doméstico de primeira necessidade. Ou seja, nos últimos vinte anos, o homem revolucionou a sua maneira de se comunicar. Foi a revolução dos meios de comunicação e o aprimoramento dos meios de transporte que viabilizaram o incremento e a velocidade ${ }^{5}$ do processo de "globalização". A globalização financeira ${ }^{6}$, ou melhor, a mundialização ${ }^{7}$, que, em 1988, era uma promessa posta em discussão, é, hoje, uma realidade inafastável. Constatar esta circunstância é admitir como lugar comum ${ }^{8}$, a um só tempo, a revolução dos meios de comunicação e a busca por uma nova concepção em torno do princípio da publicidade.

Esse é o binômio fundador: meios de comunicação e princípio da publicidade. Aplicar e/ou interpretar o princípio da publicidade, compreendido enquanto norma, hoje, exige uma nova concepção. Uma concepção que, por exemplo, por um lado, não ignore o efeito estigmatizante potencializado pela exploração sensacionalista promovida pela mídia acerca de um fato supostamente delituoso, e que, por outro, não presuma a citação do réu quando esta foi feita por edital ${ }^{9}$. Enfim, o novo quadro social que se apresenta reclama uma reconstrução do princípio da publicidade, quer para inibir a informação perniciosa aos direitos fundamentais ${ }^{10}$ (direito à imagem, à honra etc.), quer para potencializar a informação relevante às garantias fundamentais (o contraditório, a ampla defesa etc.).

É em meio à necessidade por uma nova concepção em torno do princípio da publicidade, que se faz mister destacar, também, que a revolução pela qual passa tal princípio, deve ser analisada com cautela. Isto porque, no mundo pós-moderno contemporâneo, tal revolução é marcada pela lógica da performance $e^{11}$ e tem na velocidade ${ }^{12}$ seu valor fundamental. Ou seja, a revolução pós-moderna do princípio da publicidade exige não apenas a máxima divulgação da informação, mas também a máxima velocidade desta. Isto ocorre porque, na sociedade pós-moderna, a informação é a nova moeda de troca da sociedade, do que se pode inferir que a televisão é meio de produção capitalista. 
Neste cenário, então, a publicidade torna-se o melhor veículo para o consumo ${ }^{13}$ da informação, ao passo que a velocidade constitui-se garantia de satisfação do cidadão. Cidadão que, em verdade, tende a desaparecer e a se transformar num novo agente social: o consumidor ${ }^{14}$. Isto se dá, pois, no mundo pós-moderno, o mesmo meio de comunicação que viabiliza a publicidade, intensifica a fragmentação social $^{15}$ (o outro é visto como um estranho ${ }^{16}$ ), é o meio de comunicação que deveria promover a interação social, mas que, em verdade, acaba por potencializar o abismo existencial entre os indivíduos e fomentar a crise do sistema representativo democrático. Sendo assim, o cidadão tende a desaparecer à medida que o indivíduo desconfia do outro, que é intensificado o processo de fragmentação social, que a participação dá lugar à acomodação, que o desempenho torna-se o rótulo de qualidade do conhecimento produzido e a verdade ${ }^{17}$, por sua vez, é descartável.

Se é certo que tal cenário que caracteriza a pós-modernidade não encontra consenso entre os sociólogos ${ }^{18}$ e os filósofos ${ }^{19}$, que nem a própria pós-modernidade é um consenso (daí o emprego da locução modernidade $\operatorname{tardia}{ }^{20}$ ) entre eles, também é certo que a transformação pela qual está passando a publicidade, a partir de meados do século $\mathrm{XX}$, é fato inegável. É a partir desse momento que o cidadão, até então aferrado às ondas do rádio e preso aos grilhões das letras de imprensa, deixa de ser o cidadão-leitor (ou cidadão-ouvinte) para se tornar, então, o cidadão-telespectador. A televisão reconstrói a relação do cidadão com a informação e a sua função na sociedade democrática. Não é demasiado afirmar que o surgimento da televisão é marco que divide a história da democracia contemporânea. É preciso refletir acerca das repercussões trazidas pela televisão para democracia.

Com efeito, se a televisão propiciou a deflagração do processo de metamorfose do princípio da publicidade, também é certo que a informática e, notadamente, a internet também contribuíram em muito para a velocidade desse processo. A combinação dos avanços proporcionados pela informática e pela televisão veio a desencadear uma nova lógica, qual seja, a do hiper-real ${ }^{21}$. Mas, antes de abordar esta, bem como outras questões relevantes, é necessário analisar o mal- 
estar produzido pela modernidade, sobre o qual disserta Sigmund Freud, e refletir em que medida o princípio da publicidade já reclamava, ou não, uma reconstrução sob o prisma da sociedade moderna e do mal-estar por esta causado. Tal reflexão ganha ainda mais importância quando se põe em relevo, por mais uma vez, que a própria terminologia, qual seja, pós-modernidade, e a sua existência não são lugares comuns na seara acadêmica.

Portanto, compreender o princípio da publicidade é tarefa que requer uma abordagem transdisciplinar ${ }^{22}$, que recorte o aludido princípio seja a partir de um viés sociológico, seja com espeque num viés psicanalítico. E isso se faz indispensável tanto porque o Direito não se resume à Constituição, tomada em seu sentido formal, quanto porque o princípio da publicidade, nela inscrito, considerado enquanto norma, requer não apenas o exame do texto da lei, mas também e, sobretudo, a análise do fato da vida. Ora, se Direito é prudência ${ }^{23}$ e se a norma não é lei, mas a síntese dual e pulsante de texto e fato voltada à resolução de um problema, o princípio da publicidade não pode ser exclusivamente apreciado sob o prisma jurídico, sob pena de o Direito afastar-se de sua razão legitimadora, qual seja, a realização da justiça.

Se Direito e Justiça não se confundem, mas este deve estar voltado a alcançar aquela, o princípio da publicidade, como norma que é, deve ser examinado sob a perspectiva sociológica, de sorte a melhor se compreender a sua repercussão no seio social e os usos e abusos que a aplicação deste princípio tem ocasionado nos dias atuais em nome da Justiça. Ou seja, a interpretação do princípio da publicidade nos dias atuais que não esteja atenta aos efeitos sociais por esse causados, é, antes de mais nada, uma interpretação deficitária, incompleta e que conduz à prática de injustiças.

Em outros termos, a aplicação e interpretação do princípio da publicidade alheia às consequências sociais, nefastas ou não, afronta a Constituição tomada em seu sentido material, isto é, colide com outros valores caros à Constituição, a exemplo da intimidade. Como salienta Eros Roberto Grau, não se deve interpretar a Constituição em tiras ${ }^{24}$, ora, se assim é, não se deve interpretar o princípio da publicidade de forma isolada, descolado do contexto social no qual se situa a Constituição, os seus valores e o intérprete. Se a Constituição é um corpo harmônico de valores, a interpretação do princípio da 
publicidade deve ser sistêmica, à medida que este se encontra entrelaçado na teia de valores que é a Constituição material ${ }^{25}$. Se a Constituição não é mera folha de papel ${ }^{26}$, esta e o princípio da publicidade nela encerrado devem ser interpretados, teleológico e axiologicamente ${ }^{27}$, de sorte a poderem ser compreendidos enquanto sistema aberto ${ }^{28}$ e mutável $^{29}$.

De outro lado, se o princípio da publicidade é norma, isto também implica que o estudioso do direito, ao interpretar a Constituição e as normas nelas insertas, não deve se ater apenas e tão-somente ao seu texto, mas deve também deter sua atenção para com o sujeito que realiza a interpretação, enquanto sujeito que conhece e que concebe a norma. Se assim é, força é convir que a refundação do princípio da publicidade exija que este seja apreciado também sob o ângulo psicanalítico, à medida que é tomado enquanto esforço de interpretação e ato ideologicamente controlado ${ }^{30}$, e, nesse sentido, não pode se descurar quer da pré-compreensão do intérprete ${ }^{31}$, quer do círculo hermenêutico ${ }^{32}$ no qual este se encontra envolto, quer do dilema que assalta a modernidade, decorrente da civilização, o embate entre segurança nas relações e liberdade individual.

Mas tais palavras iniciais não estariam completas sem antes delimitar mais precisamente o objeto do presente trabalho, qual seja, uma nova concepção do princípio da publicidade no processo penal face às inovações tecnológicas e ao papel marcante que a televisão desempenha nos dias atuais. Ou seja, o que se pretende, portanto, é propor uma nova concepção para o princípio da publicidade, diante dos malefícios que podem ser causados ao cidadão que responde a um inquérito policial ou a um processo penal em decorrência da exploração jornalística do fato. Em outros termos, o que motivou a realização da presente pesquisa é a circunstância de perceber como um suposto autor de um delito, mesmo antes do inquérito policial e do devido processo legal, mesmo abrigado pela presunção constitucional de inocência, pode ser transformado do dia para noite pelos meios de comunicação, em especial pela televisão, no inimigo número um de uma nação.

Portanto, uma nova concepção acerca do princípio da publicidade no processo penal demanda que se discuta com seriedade a maneira como as autoridades públicas divulgam as informações, bem como a forma como tais autoridades dão acesso à informação decorrente do inquérito ou do processo penal aos mecanismos de imprensa, em 
especial a televisão. As autoridades públicas, por um lado, não podem negar o acesso à informação de maneira injustificada, mas, por outro, não devem realizar o seu trabalho para a televisão ou em razão desta. Ou seja, as autoridades "publicitárias" não podem usar o processo penal como forma de se promoverem perante a "opinião publicada", de sorte a, no momento seguinte, pleitearem novos aumentos salariais e valorizarem as suas carreiras profissionais.

Ademais, estas mesmas autoridades não podem se "prostituírem" perante os meios de comunicação, na busca de sua autopromoção. Em outras palavras, neste jogo, no qual os meios de comunicação obtêm o "furo jornalístico" e com isso ganham preciosos segundos de audiência, ao mesmo tempo em que valorizam seu minuto publicitário, não se pode admitir a possibilidade das próprias autoridades públicas venderem o referido "furo" para os meios de comunicação e cobrarem caro por isso. Isto seria mais do que a espetacularização do processo penal, seria o cúmulo da falta de escrúpulo. Não se pode tolerar a possibilidade de o processo penal ser utilizado por suas autoridades contra o próprio Estado e os seus cidadãos como mecanismo de barganha, como, por exemplo, em negociação de planos de carreira. É preciso estabelecer um limite!

Neste cenário de situações tormentosas, não se quer restringir a liberdade de informação, o que se deseja é compatibilizá-la com o princípio da publicidade no processo penal, bem como com a inviolabilidade à honra e à vida privada e a proteção à imagem, todas também garantias constitucionais, sob pena de responsabilização do agente divulgador pelos danos materiais e morais. Não há direitos ou garantias absolutos. É bom lembrar que nenhum dos dispositivos constitucionais que se possa mencionar a esse respeito são normas, pois não passam de textos. Não se deve jamais esquecer disso!

Justamente por isso, não se visa, com uma nova concepção acerca do princípio da publicidade no processo penal, uma lei que restrinja a liberdade de informação jornalística, até mesmo porque esta acabaria sem qualquer utilidade prática. O que se busca é uma análise diferenciada de cada caso a partir de um prisma respaldado na equidade, afinal não existem soluções fáceis ou inquestionáveis. As decisões são sempre possíveis, persuasivas e argumentáveis. 
Não se tem aqui a pretensão de proteger criminosos, mas a intenção de resguardar inocentes. Não se trata de um hino à impunidade, vez que qualquer cidadão pode se ver diante da circunstância de responder a um processo penal, mas de uma conclamação à racionalidade. Enquanto a televisão opera com a emoção com a finalidade de alcançar altos índices de audiência, o processo penal subordina-se à lógica do devido processo penal. A televisão precisa de vilões e de heróis, as telenovelas são maior exemplo disso, mas o processo penal não pode ser palco para as câmeras, mas espaço para a racionalidade.

Diga-se, ainda, que não se tratará aqui do sigilo no inquérito policial em especial, mas no processo penal, tomado numa concepção ampla. Logo, não se aguarde que seja feita qualquer análise de artigo ou texto de lei, como, por exemplo, do artigo 20 do Código de Processo Penal: esse não é o escopo. A finalidade é reconstruir o princípio constitucional da publicidade no que toca à sua aplicabilidade no processo penal num sentido amplo.

De sorte a percorrer este caminho, buscar-se-á, primeiramente, esclarecer a relação do princípio da publicidade com a liberdade de imprensa e com a garantia de acesso à informação. Tal providência torna-se necessária seja para evitar que se faça qualquer confusão entre tais institutos jurídicos, seja para destacar que não se cometeu aqui o equívoco de tratar sobre o princípio da publicidade, quando, em verdade, dever-se-ia analisar a liberdade de imprensa, seja, ainda, para demonstrar os laços estreitos que tais institutos mantêm entre si. Por conseguinte, à medida que se examina a relação travada entre o princípio da publicidade e a liberdade de imprensa, dirimem-se dúvidas, evitamse equívocos e confere-se consistência aos argumentos.

\subsection{O PRINCÍPIO DA PUBLICIDADE E SUA RELAÇÃO COM A LIBERDADE DE IMPRENSA}

Convém esclarecer, ainda, nessa introdução, que não se faz aqui o equívoco de confundir o princípio da publicidade com a liberdade de imprensa ${ }^{33}$. Em verdade, o que se busca é estabelecer uma relação necessária e dialética entre ambos, de sorte a obter como resultado uma nova concepção acerca do princípio da publicidade que permita extrair desse outras consequências ainda não obtidas. Mas para que se 
possa estabelecer os limites desta relação, impõe-se como pressuposto precisar, ainda que de forma perfunctória, o que se entende por princípio da publicidade e por liberdade de imprensa.

A expressão princípio da publicidade, apesar de singela, contém uma densa carga semântica. Carga esta que possui caráter de norma e natureza de garantia ${ }^{34}$. Se assim é, impende extrair dessa circunstância algumas consequências. A primeira é que o princípio da publicidade, enquanto norma, é, simultaneamente, texto e fato. Mas, quanto a isto, não se faz necessário discorrer nesta ocasião, vez que algumas linhas prévias já foram escritas. Contudo, uma outra consequência também pode ser obtida a partir do princípio da publicidade, qual seja, este se trata de uma garantia e, como tal, uma norma assecuratória ${ }^{35}$. Sendo assim, o princípio da publicidade é escudo que protege o direito. Mas qual seria este direito e de quem este deve ser protegido?

$\mathrm{O}$ direito que se protege depende do caso, de quem o exerce e contra quem ele é exercido. Nos limites do presente trabalho, o direito em questão é o da liberdade de imprensa. Por conseguinte, a liberdade de imprensa tem natureza jurídica de direito, direito este que tem como titulares imediato e mediato, respectivamente, a imprensa e a sociedade civil $^{36}$. Ora, se assim é, cada cidadão, enquanto elemento participativo integrante da sociedade civil é também titular do referido direito. Vêse, desta forma, que a liberdade de imprensa não é direito de titularidade exclusiva, o que já contribui, portanto, para se perceber que a imprensa não pode exercer tal direito de forma totalitária. Mas, em que medida tal constatação encontra-se interligada ao princípio da publicidade? Bem, se o princípio da publicidade é garantia inserta no catálogo constitucional dos direitos e deveres individuais e coletivos ${ }^{37}$, isto implica algumas decorrências.

A primeira delas é que a garantia da publicidade deve se dirigir a proteger o cidadão do Estado e, nesse sentido, obrigar o Estado, na prática de seus atos, a providenciar a publicação dos mesmos, seja durante a sua realização, seja quando de sua conclusão. Contata-se aí o princípio da publicidade como garantia individual, ou seja, o cidadão se protege do Estado. Contudo, entender o princípio da publicidade como uma garantia individual não significa que o Estado sempre deva conferir publicidade ampla e irrestrita aos atos que pratica, pois, do contrário, em nome de obedecer tal garantia, acabaria, na verdade, aniquilando-a. 
Em outros termos, a garantia individual não pode ser exercitada contra aquele que é o seu titular, o indivíduo. Conferir a máxima efetividade à garantia individual da publicidade é ponderar de acordo com o caso concreto como esta deve ser exercitada, pois, em alguns casos, a otimização do princípio da publicidade irá significar a publicidade ampla e irrestrita dos fatos seja através do Estado, como, por exemplo, por meio do Diário Oficial, seja com a vênia do Estado, ainda que implícita, como, por exemplo, através dos meios de comunicação.

Todavia, em outros casos, obter a máxima efetividade do princípio significará nada publicar acerca dos fatos ou publicar com restrições. Nada publicar ou publicar com restrições implicará, então, imposição a ser feita quer sobre o Estado quer sobre os meios de comunicação. Isto porque, tomado como garantia individual, o princípio da publicidade não pode ser desvirtuado, seja diretamente pelo Estado, seja com a sua vênia, ainda que tácita, através dos meios de comunicação, vez que, em qualquer caso, uma garantia individual estaria sendo utilizada para produzir um estigma em torno do cidadão que é o seu titular e que deveria, em nome dela, ser protegido.

Portanto, diante do exposto, o sigilo não é alheio ao princípio da publicidade, é decorrência deste. Em melhores palavras, se o sigilo é exceção à regra que é o princípio da publicidade, convém lembrar que toda exceção é um desdobramento da regra, ou seja, não são linhas paralelas, mas linhas que se cruzam ${ }^{38}$. Insta destacar, ainda, que nada publicar ou publicar com restrições requer um aparato de fiscalização, quer com o escopo de conservar o sigilo, quer com o objetivo de preservar as restrições impostas. Do contrário, o princípio da publicidade não seria uma garantia, mas um monumento em ruína.

Não se desconhece o risco do qual o sigilo pode importar para a democracia, nem tampouco o passado totalitário da história da humanidade e a fragilidade do sistema democrático, por exemplo, na América Latina e na África. Não se compartilha aqui com este capítulo odioso da história. O que tal raciocínio acima desenvolvido busca pôr em evidência é que uma garantia individual, como é o princípio da publicidade, não pode ser desvirtuada de sorte a acabar estigmatizando cidadãos antes mesmo do devido processo legal. Isto é, o desvirtuamento de uma garantia constitucional, o princípio da 
publicidade, por meio da lógica que preside os meios de comunicação, não pode fazer tabula rasa de uma outra garantia constitucional, o princípio da presunção de inocência (a dimensão externa e material do princípio da presunção de inocência).

Ademais, convém destacar que o sigilo já é admitido em nosso ordenamento, seja no inquérito policial, seja no processo penal em juízo, na hipótese de defesa do interesse social, como, por exemplo, em nome do sucesso das investigações. Logo, a defesa que aqui se faz é a da maximização da hipótese de aplicabilidade do sigilo no caso de defesa da intimidade do suposto autor do delito. Isto é, o que se busca é o mesmo respeito que se confere ao sigilo em nome da sociedade, argumento que guarda muito mais vínculo com os antigos sistemas totalitários, do que aquele que deva se fazer em nome do indivíduo. Afinal, lembre-se, uma vez mais, o princípio da publicidade é uma garantia individual.

Uma segunda consequência é a de que a garantia da publicidade deve se destinar a proteger o cidadão não apenas do Estado, mas de outro cidadão ou de uma pessoa jurídica de direito público ou privado ${ }^{39}$. Ora, uma primeira razão para que assim se compreenda o referido princípio é a constatação de que se este se presta a proteger o cidadão frente aos possíveis abusos do Estado, deve ter também a capacidade de protegê-lo diante dos abusos que possam vir a ser perpetrados por entidades jurídicas de menor envergadura. Isto é, se protege contra o maior, o Estado, deve proteger também diante do menor, uma emissora de televisão. Outra razão que se pode arrolar é a que decorre da relação recíproca entre o referido princípio e a liberdade de imprensa. Se a liberdade de imprensa é direito que pode ser exercitado pelos meios de comunicação, também é verdade, como se destacou acima, que é direito que tem como titular toda a sociedade civil, logo, o próprio cidadão. Ora, se isso é verdade, não é possível que a liberdade de imprensa sacrifique um de seus titulares, o próprio cidadão, mesmo diante de hipóteses excepcionais como as do processo penal. Note-se que, se a liberdade de imprensa é um conquista da humanidade, a preservação da inocência e a aplicabilidade ponderada do princípio da publicidade também o são.

Mas os argumentos não se encerram aqui. A correlação entre o mencionado princípio e a citada liberdade fica mais evidenciada quando 
se vislumbra que uma nova concepção do princípio da publicidade demanda que haja uma fiscalização rigorosa em torno dos próprios agentes estatais encarregados da investigação criminal e do processo penal no sentido de como estes divulgam as informações referentes à suposta autoria do delito. É dizer, se o princípio da publicidade demanda do Estado que divulgue as informações dos atos que pratica, com maior razão, aquele também exige do Estado que não as divulgue de forma precipitada e manipulada. Por tudo isso, torna-se imperioso uma análise do princípio da publicidade no contexto da sociedade contemporânea e sob o enfoque transdisciplinar.

\section{O PRINCÍPIO DA PUBLICIDADE NA SOCIEDADE CONTEMPORÂNEA: TRANSDICIPLINAR UMA ANÁLISE}

Insta destacar, primeiramente, que abordagem que será feita nos itens subsequentes tem por finalidade analisar o princípio da publicidade a partir de uma perspectiva transdisciplinar. Ao se proceder desta forma, convém salientar que se buscará realçar a relação entre o princípio da publicidade no processo penal, a publicidade, enquanto ferramenta de expressão da liberdade de imprensa, e a televisão. A interação entre tais fatores permitirá compreender melhor este fenômeno complexo, bem como propiciará uma apreciação mais acurada das repercussões nocivas por ele produzidas no processo penal.

Por ter se feito aqui a opção por uma análise transdisciplinar é que, nos itens seguintes, analisar-se-á a relação do princípio da publicidade no processo penal e a publicidade (instrumento da liberdade de imprensa) tanto com o mal-estar produzido pela modernidade e pela pós-modernidade quanto com a televisão, bem como com a sensação de insegurança. Note-se que tal esforço é empreendido seja com o objetivo de desmascarar os efeitos criminológicos do princípio da publicidade, seja com o escopo de oferecer uma nova concepção deste a partir de uma perspectiva tópica e argumentativa.

\subsection{O PRINCÍPIO DA PUBLICIDADE E O MAL-ESTAR DA MODERNIDADE}

Inicialmente, impõe-se consignar que fazer um esforço para desvelar os sintomas e as patologias do mal-estar na civilização e a relação 
destes com o princípio da publicidade no processo penal requer um exame de pelo menos três obras da lavra de Sigmund Freud. São elas: a) Totem e Tabu (1912-13) Vol. XIII ${ }^{40}$; b) Futuro de Uma Ilusão (1927) Vol. XXI; e c) O Mal-Estar na Civiližação (1930) Vol. XXI ${ }^{41}$. Tal esforço, ainda que de forma breve, se impõe no presente caso, pois tais obras refletem em grande medida problemas relevantes com os quais a sociedade contemporânea convive, e tais problemas, por sua vez, acabam por apresentar algumas de suas repercussões na seara da ciência penal, mais especificamente, no que toca ao princípio da publicidade.

Insta salientar, desde já, que os textos mencionados dizem respeito a um grupo de pensamentos que podem ser denominados como: "Frend e as questões culturais, filosóficas e o processo de civilização dos seres

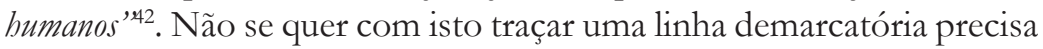
entre os trabalhos produzidos por Freud acerca do psiquismo e os voltados à cultura, vez que tal escopo restaria, desde sua origem, frustrado. O que se deseja é perceber em que medida tais nuances, na obra de Freud, permitem que se possa entrever uma relação de complementaridade entre as ditas obras e, mais que isso, em que medida tal relação repercute no Direito Processual Penal e no princípio da publicidade.

Em Totem e Tabu, o psicanalista austríaco desenvolve a ideia do mito da horda primeva mostrando a ligação do psiquismo humano com a cultura. Segundo tal mito, o homem "comedor", dono da verdade e de todos os participantes da horda, é morto e "comido" por ela. De acordo com Freud, os humanos são descendentes tanto desse homem quanto dessa horda e, por tal razão, trazem dentro de si, simultaneamente, o desejo de comer a todos, mas também o desejo de não querer ser comido, além de saber o quão é ameaçador ter um só comendo a todos. Sendo assim, é possível afirmar que esse é o grande dilema que Freud tenta demonstrar na obra e que angustia o homem, qual seja, a ambivalência ${ }^{43}$ inerente à condição humana e que, assim como marca o homem, impregna tudo aquilo que decorre dele, no presente caso, a ciência criminal e o princípio da publicidade. É, aliás, tal ambivalência que marca o princípio da publicidade no processo penal e que acabou por resultar na circunstância de que uma garantia individual viesse a ser transformada numa causa amplificadora dos estigmas decorrentes do processo penal. 
Por sua vez, no que toca à obra O Futuro de Uma Ilusão, é possível asseverar que esta demarca bem o início das reflexões mais profundas que Freud viria a fazer acerca da cultura, bem como revela o tom de desencanto deste em torno da civilização. Aliás, como paradigma desta desilusão, Freud afirma que o trabalho revela, em vários momentos, o limite do ser humano, qual seja, o de ser um animal enclausurado na cultura. Nesse sentido é que, anos mais tarde, Foucault viria a consignar que o trabalho, em verdade, é um processo social de adestramento do homem $^{44}$. Diga-se por oportuno que, na mesma obra, Freud analisa a religião e a função que esta exerce na sociedade, após o que vem a concluir que a religião está relacionada com a ilusão, ou seja, com a civilização $^{45}$, e que, por isso, desempenha um papel estratégico na sociedade. Disto resulta perceber a relação que há entre o processo de civilização e o princípio da publicidade. Quanto mais públicos os atos se tornam, mais estes são ditos civilizados. Contudo, como salienta Walter Benjamin ${ }^{46}$, tanto maior a civilização, maior será a barbárie. Ou seja, a civilização traz em si o gérmen da barbárie, pois, à medida que aquela se torna mais complexa, essa se aperfeiçoa ${ }^{47}$.

Convém esclarecer que, segundo Freud, todo indivíduo é virtualmente inimigo da civilização, embora suponha que esta constitui um objeto de interesse humano universal. Em outros termos, a civilização é um mal criado pelo homem na busca de resolver algumas de suas inquietações, mas é também o mal que enclausura o homem no cárcere criado por ele mesmo. Sendo assim, não é difícil perceber que o Direito, enquanto produto da civilização, não foge a tal regra e que esta se faz mais ainda sentida no que toca à ciência penal. Portanto, pode-se afirmar que a ciência penal, nesse sentido, é, a um só tempo, o maior depósito de ilusões do homem e o maior cárcere criado pelo próprio homem ${ }^{48}$. E, mais que isso, que essa ilusão e/ou cárcere serão tanto maior quanto maior for a publicidade ${ }^{49}$. Confere-se publicidade aos atos das autoridades públicas em geral para conferir maior segurança ao cidadão, mas essa mesma publicidade, no caso do processo penal, acaba por se tornar hoje fonte de uma crescente sensação de insegurança por parte da sociedade, bem como causa multiplicadora dos estigmas penais.

$\mathrm{Na}$ esteira desse raciocínio é que Freud averba que "há incontáveis pessoas civilizadas que se recusam a cometer assassinato ou a praticar 
incesto, mas que não se negam a satisfazer sua avareza, seus impulsos agressivos ou seus desejos sexuais, e que não hesitam em prejudicar outras pessoas por meio da mentira, da fraude e da calúnia, desde que possam permanecer impunes; isso, indubitavelmente, foi sempre assim através de muitas épocas da civilização. Se nos voltarmos para as restrições que só se aplicam a certas classes da sociedade, encontraremos um estado de coisas que é flagrante e que sempre foi reconhecido. É de esperar que essas classes subprivilegiadas invejem os privilégios das favorecidas e façam tudo o que podem para se liberarem de seu próprio excesso de privação" 50 .

Percebe-se, assim, que o dilema que marca a existência do homem e que reverbera em todas as suas ações e (cri)ações (e o princípio da publicidade no processo penal é uma delas) é o que William Shakespeare retratou com tanta fidelidade na fala de Hamlet: "Ser ou não ser... Eis a questão. Que é mais nobre para a alma: suportar os dardos e arremessos do fado sempre adverso, ou armar-se contra um mar de desventuras e dar-lhes fim tentando resistir-lhes?" 51 . Qual o mal maior para civilização: aplicar e interpretar o princípio da publicidade no processo penal como à época em que a Constituição foi confeccionada ou redimensionar tal procedimento?

Por isso a relação do homem com a ciência é uma relação tormentosa, como observou Freud, pois, ao mesmo tempo que identifica as limitações da ciência, constata que a mesma é a única estrada que leva a um conhecimento da realidade externa a si próprio, ainda que tal conhecimento não seja seguro, mas pelo menos proporcione ao homem um momento de ilusão, ou, por que não dizer, o frescor dessa sensação. Note-se que o princípio da publicidade, enquanto produto da civilização, sofre do mesmo mal, vez que se, por um lado, aparenta ser um caminho seguro, por outro, é também uma ilusão. Aliás, é esta ilusão que motiva o homem na sua busca voraz por mais informação e pelo máximo de publicidade. Perceba-se, no entanto, que a maximização da publicidade e inflação informativa são, a um só tempo, a dose de ilusão necessária para sanidade mental do homem e causa potencializadora da refutabilidade ${ }^{52}$ do conhecimento por ele produzido.

Mas é em meio a esta situação que o homem também, como salienta Freud, ao mesmo tempo em que convive com a ciência, cria para si a 
figura de "Deus", ou seja, no mesmo instante que busca refúgio em tal figura, gaba-se de ter identificado este conceito mais elevado e puro como produto de sua capacidade. Por isso, Freud identifica que a religião e a figura de Deus têm um aspecto em comum com a ciência, qual seja, elas não são uma ilusão, pois os muros erguidos por elas se fazem sentir ao longo da vida do homem e, mais que isso, ambas são frutos da civilização. Contudo, adverte ainda Freud, que ilusão também é imaginar que aquilo que a civilização não pode dar ao homem, este pode conseguir de outra forma, ou seja, ilusão é acreditar na solução singela de que os problemas do homem diminuiriam na mesma proporção que este se destituísse da civilização. Ou seja, a civilização permite enxergar o horizonte, mas de forma turva. Todavia, sem ela, o homem nem sequer enxergaria o horizonte. O mesmo se dá no que toca ao princípio da publicidade, pois, se, de um lado, é inegável que este amplifica o acesso à informação, potencializa o espaço público, viabiliza a fiscalização da discricionariedade do ato administrativo e possibilita o exercício da democracia, por outro, multiplica a refutabilidade do conhecimento, maximiza a fragmentação social, evidencia a crise da democracia, estigmatiza o acusado no processo penal ${ }^{53}$, manipula o julgamento pelo Tribunal do Júri ${ }^{54}$ e proporciona a criação de um simulacro ${ }^{55}$.

São com estas linhas preparatórias traçadas por Freud - em O MalEstar na Civilização (1930) Vol. XXI - que o mesmo se indaga: "enfim, de que nos vale uma vida longa se ela se revela difícil e estéril em alegrias, e tão cheia de desgraças que só a morte pode ser recebida como uma libertação?" 56. Note-se que a indagação formulada pelo psicanalista austríaco é, em grande medida, a indagação intrínseca e crescente do homem moderno: se a vida é uma angústia contínua, um desenrolar de contradições complementares, não seria a morte o único momento de libertação do homem? Insta destacar, desde já, que tal indagação revela, a um só momento, diversas mensagens possíveis, a saber: a) o desencanto do homem moderno com a civilização e com tudo que desta decorre e b) a atração e o prazer que a morte exerce sobre o homem. Assinale-se, por oportuno, que a refundação do princípio constitucional da publicidade no processo penal não pode desconhecer o desencanto do homem moderno com a civilização, o 
qual será tanto maior quanto maior for a publicidade dos casos criminais, vez que o dimensionamento gradual da publicidade ao longo da Era Moderna, simultaneamente, estende as fronteiras do mundo civilizado (na Era Pós-Moderna, são diminutos os lugares do globo que não tenham sido tocados pela civilização ${ }^{57}$ ), mas também aumenta o descontentamento do homem moderno para com a civilização. Isto permite, por um lado, melhor compreender o aumento dos casos de suicídio $^{58}$, a larga disseminação do uso de $\operatorname{drogas}^{59}$ e a disseminação da prática de assassinatos em série pelo homem moderno e, por outro, entender que tal ciclo será tanto mais vicioso quanto maiores forem os estigmas produzidos pelo princípio da publicidade no processo penal.

Todavia, o mesmo Freud que se indaga sobre as agruras do viver é o mesmo que, no instante seguinte, reconhece a importância da civilização na vida do homem e que, ainda, consigna que a primeira e mais importante exigência da civilização é a justiça, isto é, a garantia de que uma lei, uma vez criada, não será violada em favor de um indivíduo. Sendo assim, Freud reconhece a importância da Justiça (bem como do Direito) para o processo civilizatório e, ainda, consigna que a sua relevância, em verdade, torna-se ainda mais evidente à medida que o "curso ulterior do desenvolvimento cultural parece tender no sentido de tornar a lei não mais expressão da vontade de uma pequena comunidade, mas um estatuto legal para o qual todos - exceto os incapazes de ingressar numa comunidade - contribuíram com um sacrifício de seus instintos" 60 .

Releva notar, contudo, que o homem, ao optar pela civilização, não abandona os seus instintos, mas apenas os reprime, pois está disposto a ceder a sua quota-parte de prazer em busca de segurança, de sorte, em tese, a não se ver à mercê da força bruta ${ }^{61}$. Ou seja, a civilização é compreendida, ainda que equivocadamente, como método de contenção da barbárie. Em suma, a civilização moderna é uma opção do homem pela segurança em prejuízo do prazer. Veja-se, assim, traçando-se um paralelo, que o princípio da publicidade no processo penal foi construído historicamente como estratégia de contenção dos excessos e abusos das autoridades públicas, mas, hoje, tem sido utilizado de forma desvirtuada como fonte de autopromoção daquelas e como causa amplificadora dos estigmas que recaem sobre o suposto autor do delito. 
É em nome dessa busca pela segurança, se é que ela existe para poder ser buscada, que a civilização moderna reduz os espaços das liberdades (de locomoção, de vida íntima, dentre outras), o que faz, dentre outras formas, por meio da ampliação gradual da publicidade e pela redefinição da função social desempenhada por esta. Imaginase o princípio da publicidade no processo penal como elemento multiplicador da justiça, à medida que aumenta o controle do ato, sem, no entanto, perceber que a amplificação desvirtuada de tal princípio é também causa que confere maior capacidade de castração à civilização à medida que dimensiona os estigmas decorrentes do processo penal.

Cumpre destacar, ainda, com espeque na lição de Freud, que, se a justiça $^{62}$ desempenha um grande papel na civilização, vez que tenta proporcionar segurança ao homem, esta não cria o conceito de liberdade, em outras palavras, a liberdade não é uma dádiva da civilização $^{63}$. Ou seja, o princípio da publicidade no processo penal, ao mesmo tempo em que visa proporcionar segurança para o cidadão perante as autoridades públicas, reduz a sua autonomia diante da sociedade, que agora o etiquetará como excluído.

Se a liberdade foi maior antes da existência de qualquer civilização, também é verdade que, naquele momento, aquela não possuía o valor que hoje possui, já que dificilmente o indivíduo se achava em posição de defendê-la ${ }^{64}$. Convém lembrar, com apoio em Georg Simmel ${ }^{65}$, que qualquer valor só é um valor graças à perda de outros valores que se tem de sofrer a fim de obtê-lo. Perceba-se, portanto, que o novo papel que, gradativamente, ao longo da Era Moderna, vai sendo atribuído ao princípio da publicidade, implica, neste momento, contenção das liberdades e apelo à segurança, o que acaba por conferir ao referido princípio uma função de destaque na sociedade, à medida que é meio para viabilização do valor posto em voga, qual seja, a segurança ${ }^{66}$. Convém salientar, no entanto, que, na Era Pós-Moderna, o princípio da publicidade deixa de ser meio para se tornar um novo valor $^{67}$.

Sendo assim, sabe-se que o desenvolvimento da civilização impõe restrições à liberdade ao passo que o Direito exige que ninguém fuja dessas restrições ${ }^{68}$. Estas restrições serão tanto mais vigorosas quanto mais estas se tornam controladas pelo princípio da publicidade. Desta forma, o que provoca o sentimento num agrupamento humano do 
desejo de liberdade pode ser tanto a sua revolta contra alguma injustiça existente ${ }^{69}$, como, por exemplo, a exposição do suposto autor do delito à execração pública (e, desse modo, esse desejo pode se mostrar favorável a um maior desenvolvimento da civilização), quanto o prazer reprimido pelo mandamento de justiça da civilização ${ }^{70}$, neste último caso, serve de exemplo a inflação de leis criminais que, auxiliada pelo princípio da publicidade, reduz, gradativamente, os espaços de autonomia privada. Seja como for, tanto no que refere à revolta contra a uma injustiça existente quanto no que toca ao prazer reprimido pelo mandamento de justiça da civilização, o certo é que o princípio da publicidade, em qualquer caso, colabora para amplificação dessa sensação $o^{71}$. Nesse sentido, então, a mesma publicidade que se volta pela busca da segurança será a mesma que provocará no homem pósmoderno o desejo incontido de liberdade.

Entretanto, o anseio por liberdade pode também originar-se dos remanescentes de sua personalidade original, que ainda não se acha domada pela civilização, e, assim, nela se torna a base da hostilidade à civilização. Nesse caso, então, constata-se que o impulso de liberdade é dirigido contra as formas e exigências específicas da civilização ou contra a civilização em geral. Tal circunstância acaba por requerer um aprimoramento da civilização, ou seja, das técnicas de repressão do " $i d{ }^{p}$, vez que não é qualquer influência da civilização que tem a capacidade de induzir o homem a transformar sua natureza na de um "cão adestrado", pois o homem, de acordo com Freud, e o capitalismo ${ }^{74}$ bem soube se aproveitar desta circunstância, sempre defenderá sua reivindicação à liberdade individual contra a vontade do grupo. Note-se, assim, mais uma vez, a ambivalência da natureza humana e, por consequência, o caráter dual e pulsante do princípio da publicidade. O mesmo princípio da publicidade que protege o cidadão do Estado é o mesmo que reforça o adestramento do cidadão de acordo com as regras impostas pelo Estado e que viabiliza que o rótulo de excluído que recai sobre ele, caso não se ajuste às regras impostas.

É nesse quadro até aqui pintado que Freud se vale de uma metáfora entre pai e filhos, para, em seguida, afirmar que os filhos, sobrepujando o pai, descobriram que uma combinação pode ser mais forte do que 
um indivíduo isolado, ou seja, que a interação entre "sim" e o "não" é mais frutífera do que a escolha por uma das duas opções. Nesse sentido, Freud pontua que "a cultura totêmica baseia-se nas restrições que os filhos tiveram de impor-se mutuamente, a fim de conservar esse novo estado de coisas. Os preceitos do tabu constituíram o primeiro ‘direito' ou 'lei" 76 . A vida comunitária dos seres humanos teve, portanto, um fundamento duplo: a compulsão para o trabalho, criada pela necessidade externa, e o poder do amor ${ }^{77}$, que fez o homem relutar em privar-se de seu objeto sexual - a mulher - e a mulher em privar-se daquela parte de si própria que dela fora separada - seu filho. Ou seja, a metáfora trazida por Freud em muito é esclarecedora da nova concepção que o princípio da publicidade deve desempenhar na sociedade moderna, qual seja, o princípio da publicidade no processo penal não pode ser nem positivo nem negativo, nem segurança nem liberdade, deve ser dual, heterogêneo, ambivalente e complexo, à medida que também é fruto da civilização e produto da natureza humana.

Logo, os tabus, as leis e os costumes estabelecem novas limitações e acabam por induzir as ações tanto dos homens quanto das mulheres. Ademais, a estrutura econômica da sociedade também exerce função de destaque, pois essa acaba por limitar, segundo Freud, o espaço de liberdade remanescente. $E$, neste contexto, a mesma necessidade econômica que manipula a sexualidade será aquela que condiciona o princípio da publicidade. Enfatize-se, o princípio da publicidade também se torna um fiel guardião do poder econômico e, ao mesmo tempo, o espaço de exploração da violência. O princípio da publicidade, então, passa a explorar economicamente os instintos, fato que, aliás, é habilmente executado pelas autoridades públicas (principalmente a polícia) em conjunto com a televisão contemporânea.

Portanto, é em meio a esse quadro, qual seja, da civilização, de seu aspecto econômico, da justiça, da valorização da liberdade e da sexualidade de cada um de seus membros, que se confirma a hipótese de que a dificuldade do desenvolvimento cultural é, em verdade, uma dificuldade geral de desenvolvimento e, nesse sentido, tal confirmação remete à análise de sua origem, de sorte a remontar à inércia da libido, à falta de inclinação desta para abandonar uma posição antiga por outra nova, isto é, o estado de comodidade ${ }^{78}$ que é inerente à condição 
humana $^{79}$. O princípio da publicidade distorcido pela televisão da Era Moderna tem consciência de tal circunstância e, ciente disso, trata de, a um só tempo, aguçar o lúdico e a libido, como instrumentos condutores das massas, e atiçar o espírito de acomodação das minorias intelectuais. Ou seja, o princípio da publicidade no processo penal manipulado pelas autoridades e pela televisão, de um lado, manipula as massas, de outro, promove a acomodação das elites intelectuais. Se assim é, como destaca Ciro Marcondes Filho ${ }^{80}$, não pode o jurista do século XXI se descurar do exame acurado do princípio da publicidade, pois este, enquanto norma, também é fato e, enquanto fato, também é um fenômeno social.

Desta forma, torna-se mais fácil perceber que, se a civilização impõe sacrifícios tão grandes, não apenas à sexualidade do homem, mas também à sua agressividade, podemos compreender melhor porque lhe é difícil ser feliz nessa civilização ${ }^{81}$. Sendo assim, percebe-se que, se, por um lado, o homem rudimentar se achava em situação melhor, sem conhecer limitações ao seu instinto, por outro, suas perspectivas de atingir o gozo, por qualquer período de tempo, eram bastante frágeis. $\mathrm{Na}$ Era Moderna, a interação entre o princípio da publicidade no processo penal e a televisão acabou por mercantilizar o gozo ${ }^{82}$, por incitar a agressividade humana à medida que se tornam produtos consumíveis. Em suma, a referida combinação eterniza o gozo, antes efêmero, proporcionado por meio da violência, com o escopo de comercializá-lo, mas também deprime o homem desencantado com o mundo. Em outras palavras, o enlace entre o princípio da publicidade e o ecrã cria um mundo real mais real do que o real (um mundo de plasma) ${ }^{83}$, no qual o homem é capaz de alcançar o gozo, mas que acaba levando-o à depressão com o mundo não-real (natural) que o cerca.

Destarte, o homem civilizado trocou uma medida de sua possibilidade de prazer por uma medida de sensação de segurança. Não se deve olvidar, entrementes, que na família primeva somente o líder desfrutava da liberdade instintiva; os demais membros estavam sujeitos à opressão servil. Durante o período mais rudimentar da civilização, o contraste entre uma minoria que desfrutava das vantagens da civilização e uma maioria privada dessas, era, portanto, levada ao extremo. Extremo que é explorado pela junção entre o princípio da 
publicidade e a televisão, ao mesmo tempo em que reconstruído por essa. Publicidade que, num primeiro momento, exibe o desfrute de uns e destaca a privação de muitos, mas que, no momento seguinte, insere o homem no "ciberespaço" ${ }^{\text {"84 }}$, cria a aparência de inclusão para o excluído.

Convém ressaltar ainda que, no que tange aos povos primitivos que ainda hoje existem, que estão sob forte risco de desaparecimento, a vida instintiva desses não é, de maneira alguma, passível de ser desejada, por força da liberdade que gozam, por parte da civilização. Note-se, como adverte Freud, que tais povos primitivos estão subordinados a restrições de outra natureza, talvez mais drásticas do que aquelas que dizem respeito ao homem moderno. E tais restrições a despeito de serem, por si só, elementos motivadores do processo de civilização, são também, em grande medida, reconstruídas e disseminadas por meio da conjunção entre o princípio da publicidade no processo penal e a televisão. Em outros termos, a publicidade vende o mundo civilizado, seja por meio do lúdico seja por meio do instinto e, desta forma, aprimora o mecanismo cultural que enreda o homem moderno nas teias da civilização.

Seja como for, esse embate entre a civilização e a horda primeva, no contexto da liberdade dos instintos, apresenta uma grande relevância que se quer destacar aqui, qual seja, à medida que, com a civilização, a agressividade do homem moderno é introjetada e internalizada, ou seja, reprimida, esta é remetida de volta para o lugar de onde proveio, isto é, dirigida ao ego do homem civilizado ${ }^{85}$. Em outros termos, esta é reprimida pelo superego, enviada ao ego e, desta forma, acaba por ocasionar duas circunstâncias, são elas: a) a eclosão do sentimento de culpa ${ }^{86}$; e b) a construção de uma mágoa, a qual acaba por marcar o $i d$ do indivíduo civilizado ${ }^{87}$. Em quaisquer das hipóteses, a relação entre o princípio da publicidade no processo penal e a televisão desempenha um papel proeminente, seja porque colabora decisivamente para o processo que reprime a agressividade, seja porque fomenta o sentimento de culpa, seja, enfim, porque manipula o sentimento de mágoa.

Por isso é que Freud, em determinada passagem de seu texto ${ }^{88}$, parece insinuar que se fosse possível colocar essa circunstância em maior harmonia com o que já se sabe sobre a história da origem da consciência, 
ficar-se-ia tentado a defender a afirmativa paradoxal de que a consciência é o resultado da renúncia instintiva ${ }^{89}$, ou que a renúncia instintiva (imposta ao homem de fora para dentro) cria a consciência, a qual, então, exige mais renúncias instintivas. De uma maneira ou de outra, a interação entre o princípio da publicidade no processo penal e a televisão também aqui se apresenta de forma relevante, visto que, de um lado, colabora para o processo de renúncia instintiva e, de outro, auxilia no processo de criação da consciência.

Diante do até aqui exposto, a obra de Freud nos provoca, dentre outras, as seguintes reflexões: a) O sentimento oceânico realmente existe?; b) O que é o primitivo de um ser humano?; c) Quais as origens do sofrimento humano?; d) $\mathrm{O}$ que resulta desse primitivo quando em contato com esse sofrimento?; e) O que faz o homem diante do conflito entre o instante de prazer e a sensação de segurança?; e, por fim, f) Em que medida estas indagações encontram-se relacionadas a uma nova concepção acerca do princípio da publicidade no processo penal?

A tais indagações não se pretende formular soluções, mas aproximações. Nesse sentido, é possível afirmar, por exemplo, no que tange aos aspectos primitivos que o ser humano traz consigo, que as condições da formação do psiquismo infantil se assemelham às psicoses e ao mito do pai primevo, e que, nas três situações, os limites da consciência decorrentes da civilização não se encontram constituídos. Nesse sentido, então, a união entre o princípio da publicidade no processo penal e a televisão, na Era Pós-Moderna, sabedora de tal circunstância, irá trabalhar com tal dado, de sorte a aperfeiçoar a manipulação do discurso da linguagem ${ }^{90}$ e a exploração do lúdico ${ }^{91}$.

Por outro lado, quanto às origens do sofrimento humano, é cabível consignar que o limite ao primitivo provém quer do próprio corpo quer do mundo externo, ou, ainda, dos relacionamentos com os outros homens. De qualquer forma, o importante a destacar é que este sofrimento exercerá um papel relevante tanto para as ciências em geral quanto para a ciência penal. Ou seja, o sofrimento, assim, é trabalhado pela interação entre o princípio da publicidade no processo penal e a televisão quer no que se refere ao relacionamento do homem com o seu próprio corpo, quer no que concerne o relacionamento do homem com o outro. A publicidade cria e recria o corpo, tomando este como limite do ser primitivo e fonte de conflito com o ser civilizado ${ }^{92}$. Mas 
a mencionada interação também reconstrói o outro, o qual, a Era PósModerna, tornar-se-á, cada vez mais, o estranho ${ }^{93}$.

Por sua vez, no que concerne à dualidade do homem entre o prazer e a realidade, dualidade que tatua de forma indelével a existência humana ${ }^{94}$, o homem se vê coagido ou a buscar de forma voluntária o isolamento ou a passar para o ataque à natureza e sujeitá-la a sua vontade seja por meio das drogas, seja através do trabalho, seja pela via da religião, seja, ainda, por meio da arte ${ }^{95}$. Seja como for, o que Freud procura deixar bem destacado em sua obra é que não há fórmulas, não existe uma regra de ouro, não há padrões ou modelos que se apliquem a todos, isto é, todo ser humano precisa descobrir através de si mesmo de que forma singular pode alcançar a sua autorrealização. Contudo, em meio a esse contexto, torna-se imperioso consignar que os mais diferentes tipos de fatores irão operar a fim de dirigir sua escolha. Em outros termos, fatores decorrentes da civilização e do mundo externo irão interferir, de sorte a tornar complexo o ato de escolha. De outro lado, convém lembrar que qualquer escolha levada a um extremo condena o indivíduo a ser exposto a perigos. Enfim, nesse sentido, pode-se afirmar que a escolha é um problema. A interpenetração entre o princípio da publicidade no processo penal e a televisão manipula o ato de escolha, seja porque oculta a natureza problemática deste, seja porque se substitui a escolha feita pelo homem. Em termos mais claros, a combinação entre o princípio da publicidade no processo penal e a televisão, na Era Pós-Moderna, não irá dar ao homem a possibilidade de escolha, fará, antecipadamente, a escolha em seu lugar. Note-se, contudo, que a própria filosofia adverte que a escolha, no mundo hiper-real ${ }^{96}$, pode ser apenas uma ilusão de liberdade, diante dramaticidade da existência ${ }^{97}$.

Portanto, seja qual for a maneira por meio da qual se possa definir o conceito de civilização, constitui fato incontroverso que todas as coisas que o homem busca a fim de se proteger contra as ameaças oriundas das fontes de sofrimento fazem parte dessa mesma civilização. Logo, à medida que o homem é civilizado, este almeja uma sensação da segurança ${ }^{98}$, mas, ao mesmo tempo, o homem se vê (ex)posto a novos e misteriosos perigos. Desta forma, percebe-se que a civilização é um processo e que, como tal, encontra-se em constante retroalimentação. Por isso é que Freud, na presente obra, conclui com a indagação de 
que se deve aqui lembrar por mais uma vez: "de que nos vale uma vida longa se ela se revela difícil e estéril em alegrias, e tão cheia de desgraças que só a morte é por nós recebida como uma libertação?"99. É nesse contexto, como se verá a seguir, que a interação entre o princípio da publicidade no processo penal e a televisão, no mundo pós-industrial, brinca com os riscos, ironiza o cotidiano e explora com humor a própria desgraça humana.

O certo é que o homem em meio a tais angústias constrói seu "Deus de prótese", quer como refúgio, quer como marca da civilização, quer como estratégia de autoafirmação. Nesse sentido, este "Deus" não é um "Deus" ao qual o homem serve (um Deus cristão), mas o qual serve ao homem (um Deus judeu) ${ }^{100}$. Um Deus de plástico exibido numa vitrine ${ }^{101}$. O mesmo homem que se integra a uma comunidade e que deve obedecer ao poder desta à medida que este poder é reconhecido como Direito. Mas o homem que cria o Direito é o mesmo que se vê subordinado, por si próprio, a ver seu instinto, sua agressividade identificada como força bruta. Nesse sentido, então, pode-se asseverar que, de acordo com Freud, a exigência primordial da civilização é a da justiça, ou seja, a garantia de que uma lei, uma vez criada, não será violada em favor de um indivíduo. Todavia, a lei é, a um só tempo, o monumento maior da civilização e o instrumento mais aprimorado da violência humana ${ }^{102}$. Por isso é que, no mundo moderno, é preciso assegurar a publicidade da lei ou, pelo menos, a presunção, ainda que retórica, de sua publicidade, vez que esta acabará por conferir à lei, na Era Moderna, a qualidade de argumento de autoridade ${ }^{103}$.

Contudo, a civilização não é um processo de fácil realização, pois, por vezes, até mesmo de forma inconsciente, o homem se boicota e não absorve cultura, de sorte a não abandonar uma posição antiga por outra nova. Nesse sentido, o embotamento é processo de resistência desenvolvido de forma inerente e inconsciente pelo homem para manutenção de seu status quo ${ }^{104}$. Nestes termos, pode-se afirmar que a civilização moderna também provoca um mal-estar à medida que tem como projeto o incremento de uma nova ordem. Dito em melhores palavras, o mal-estar gerado pela civilização decorre da imposição de uma mudança. Mudança que não tem ponto de chegada, que não meio, mas que é o próprio fim ${ }^{105}$. A mescla entre o princípio da publicidade no processo penal e a televisão, nesse sentido, ao mesmo 
instante que acelera o processo de mudança ocasionado pela civilização, trata de ocultá-lo e ministrá-lo em doses homeopáticas mais constantes, de sorte a diluir as possíveis resistências e a proporcionar uma acomodação ${ }^{106}$ diante das transformações sociais, políticas, econômicas e culturais.

Releva-se notar, então, que, nesse contexto, a crítica ao outro acaba por se constituir a repetição deste outro. Dito em outros termos, a crítica ao outro é a projeção que o homem faz de si próprio sobre o outro, à medida que o homem não é o outro, mas deseja ser ele. Destaque-se, já aqui, que a publicidade, na era pós-moderna, utilizarse-á habilmente de tal circunstância, seja quando repete o ato de fala ao esmo, no limite do insuportável, seja quando repete os modelos estereotipados na tentativa de diluir as diferenças entre os homens e manipular o seu ato de escolha. A repetição é segura e cômoda, ao passo que a escolha é problemática e tormentosa ${ }^{107}$. Disto decorre, dentre outros aspectos, que a agressividade, uma vez desconstruída, se transforma em sentimento de culpa e se reconstrói em forma de pedido de desculpa. Sendo assim, quanto mais culpa, mais se pede desculpa e mais agressividade se instala e mais culpa se deflagra. E assim sucessivamente ${ }^{108}$. Instala-se, assim, um ciclo vicioso que se retroalimenta. O certo é que, diante deste quadro repetitivo, a consciência surge através da repressão de um impulso agressivo, sendo subsequentemente reforçada por novas repressões do mesmo tipo e que, em última análise, de acordo com Freud, Jesus Cristo, ao mesmo tempo, que é perdão, é culpa; no mesmo instante que é misericordioso, é também o pai primevo comedor, o senhor do castigo ${ }^{109}$. Neste quadro é que a união entre o princípio da publicidade no processo penal e a televisão, no mesmo instante que enaltece, estigmatiza, no mesmo momento que cria heróis, fabrica vilões, no mesmo tempo que constrói mitos, os descarta ${ }^{110}$.

Ante o exposto, Freud conclui: “a questão fatídica para a espécie humana parece-me ser saber se, e até que ponto, seu desenvolvimento cultural conseguirá dominar a perturbação de sua vida comunal causada pelo instinto humano de agressão e autodestruição. Talvez, precisamente com relação a isso, a época atual mereça um interesse especial. Os homens adquiriram sobre as forças da natureza um tal controle, que, com sua ajuda, não teriam dificuldades em se exterminarem uns aos 
outros, até o último homem. Sabem disso e é daí que provém grande parte de sua atual inquietação, de sua infelicidade e de sua ansiedade. Agora só nos resta esperar que o outro dos dois 'Poderes Celestes', o eterno Eros, desdobre suas forças para se afirmar na luta com seu não menos imortal adversário. Mas quem pode prever com que sucesso e com que resultado?" "111. É exatamente a fragilidade da segurança proporcionada pela civilização durante a Era Moderna e os seus elevados custos para natureza humana que levam o homem, no momento seguinte, agora na Era Pós-Moderna, ao primado da liberdade sobre a segurança. E, nesse novo contexto que se desenha, é que se faz necessário, uma vez mais, redefinir o papel o princípio constitucional da publicidade no processo penal.

\subsection{O PRINCÍPIO DA PUBLICIDADE E O MAL-ESTAR NA PÓS-MODERNIDADE}

Somente a sociedade moderna refletiu sobre si mesma como um produto da "cultura" ou da "civilização" e atuou sobre esse autoconhecimento com os resultados que foram aprofundadamente analisados por Freud, conforme foi destacado anteriormente. Sendo assim, a expressão "civilização moderna", como bem destaca Bauman ${ }^{112}$, é, por essa razão, um pleonasmo, vez que toda civilização é moderna, à medida que só nesta era o homem se perguntou sobre si mesmo e se questionou sobre os resultados da civilização. Portanto, o princípio publicidade enquanto conquista da civilização demanda que o intérprete, ao aplicá-lo, questione-se sobre si próprio e, principalmente, sobre os resultados decorrentes de sua aplicação no tecido social.

Se é certo que na Era Moderna a segurança foi o grande farol a iluminar o caminho da humanidade, também é preciso que esta mesma segurança (ou ordem) trouxe consigo os mal-estares denunciados por Freud, quais sejam, a "compulsão", a "regulação", a "supressão" ou a "renúncia forçada", os quais, em grande medida, são consequências evidentes do binômio: "excesso de ordem" e "escassez de liberdade" A busca desesperada da modernidade pela segurança, diante da tripla ameaça oculta na fragilidade do corpo, na natureza selvagem do mundo empírico e na agressividade ínsita ao homem, acaba por justificar o sacrifício da liberdade do indivíduo na busca pelo prazer. Neste quadro, 
então, a busca pelo prazer é compreendida como causa de mal-estar ao mesmo tempo em que o excesso de ordem também acabava por redundar neste. Ora, se isto é verdade, a interpretação e aplicação do princípio da publicidade, o qual não é, diga-se uma vez mais, um mero texto, requer do intérprete a cautela em não se deixar obcecar pela busca de segurança, face aos mal-estares por esta causados.

Diante disso, então, como antítese à tese instalada no seio social, na Era Pós-Moderna, o homem prefere a desregulamentação à ordem normativa, vez que, agora, o prazer é o juiz que sentencia a condenação da segurança. Nesta nova era, da qual nos fala Edgar Morinn ${ }^{114}$, a liberdade é o valor de referência, sem, no entanto, olvidar a beleza, a ordem e a pureza, os quais, agora, devem ser perseguidos por meio da espontaneidade, do desejo e do esforço individual. Por esta razão é que Bauman ${ }^{115}$ assevera que a pós-modernidade não deve ser serva da liberdade, mas, sim, combatente da interação entre essa e a segurança, isto é, a civilização não deve ser parte, mas todo, logo, deve ser ambivalente, como dual é a natureza humana e, portanto, tudo que decorre do homem, logo, o próprio princípio da publicidade.

Negar a ordem é negar a insegurança inerente à existência humana, bem como pregar o fenecimento da liberdade, é castrar o demasiadamente humano instinto de prazer. Talvez, por isso, séculos antes de Freud, Aristóteles já houvera afirmado, referindo-se à justiça ${ }^{116}$, que esta está no meio e não nas extremidades ${ }^{117}$. Mas o ponto de equilíbrio não é fórmula fácil, não é modelo, mas diferença, própria da perpétua autocriação do humano. E é, neste diapasão, que deve se inserir uma nova concepção acerca do princípio da publicidade, pois, se este é norma, esta também é ambivalente, à medida que é geral e especial a um só tempo, vez que, enquanto texto redigido pelo legislador, é genérica e, enquanto fórmula de decisão do magistrado, é específica. Mas, não apenas isto. A aplicação e interpretação do princípio da publicidade não podem negar a ordem nem tampouco sustentar a exclusão da liberdade, pois, de um lado, tal princípio conduziria ao drama da insegurança inerente à condição humana e, de outro lado, levaria à castração do prazer. Ou seja, o princípio da publicidade nem pode ser levado ao extremo, na busca pela fiscalização de todos os atos e redução dos espaços de vida íntima, a exemplo do reality show ${ }^{118}$, 
nem tampouco deve ser restringido por apreço excessivo à liberdade individual.

Desta forma, o homem e mulher pós-modernos trocaram um quinhão de suas possibilidades de segurança por uma porção de felicidade ${ }^{119}$. Se, na modernidade, o mal-estar proveio da circunstância da segurança tolerar uma liberdade diminuta demais na busca da felicidade individual, na pós-modernidade, o mal-estar decorre de uma espécie de liberdade de procura do prazer que admite uma fração irrisória de segurança individual. De qualquer forma, tanto a liberdade quanto a segurança são valores, valores que só permaneceram como valores em razão do descarte de outros valores, o qual precisa acontecer afim de que esses sejam auferidos ${ }^{120}$.

Todavia, se, por um lado, o descarte determina o valor, por outro, esse implica maior necessidade. Ou seja, quando a liberdade encontra, num dado momento, o seu valor máximo, no momento seguinte esta será sacrificada no altar da segurança, quando, então, logo em seguida, a segurança será abatida no templo da liberdade individual. Em quaisquer das situações, a felicidade soçobra. Desta forma, fica perceptível que aferir o sentido do princípio da publicidade é ponderar valores, quais sejam, segurança versus liberdade, certo de que tal ponderação não é nunca generalizável, mas sempre singular ${ }^{121}$ enquanto resultante de um esforço de equidade ${ }^{122}$. Entenda-se, portanto, neste contexto, felicidade como mandato de otimização ${ }^{123}$, no caso, do princípio da publicidade.

Aliás, Freud, cônscio de tal circunstância, é que assevera que “(...) supomos, assim, que só se pode extrair intenso deleite de um contraste, e muito pouco de um estado de coisas" ${ }^{124}$. Alguém poderia se perguntar: por quê? Porque "o que chamamos de felicidade (...) vem da (preferivelmente repentina) satisfação de necessidades represadas até um alto grau e, por sua natureza, só é possível como fenômeno episódico" 125 . Ou seja, de acordo com Freud, a felicidade é fenômeno que pressupõe castração e fugacidade. Logo, a liberdade sem segurança não implica maior felicidade, nem o inverso é verdade. Sendo assim, se a pós-modernidade requer a reavaliação de valores, e se reavaliar pode propiciar um momento de felicidade, não se deve olvidar, também, que reavaliar não garante necessariamente um estado de satisfação. 
Não há ganho sem perda, por isso, a virtude, no caso a otimização do princípio da publicidade, está no ponto de equilíbrio, mas o ponto de equilíbrio não é o resultado de uma análise matemática dos custos e benefícios ${ }^{126}$, vez que o que agora é custo, no momento seguinte, pode ser benefício, logo, o custo e o benefício não são, mas estão, e isto torna a busca pelo equilíbrio ainda mais tormentosa. E este tormento se agrava à medida que se percebe que o ponto de equilíbrio do princípio da publicidade não é uma verdade demonstrável, mas argumentável ${ }^{127}$. Portanto, enquanto esforço de argumentação, o meio, do qual fala Aristóteles, não é resultado exclusivo de ato de conhecimento, mas combinação deste com o ato de persuasão ${ }^{128}$. Logo, uma nova concepção do princípio da publicidade não é estática, não é produto de ciência, vez que é, a um só tempo, ato de interpretação e argumentação. Desta forma, o princípio da publicidade escorado num catálogo de $\operatorname{argumentos}^{129}$ deve ser o resultado do esforço para se alcançar um lugar comum ${ }^{130}$, após terem sido testados os argumentos que o legitimam e a resistência destes diante do auditório ${ }^{131}$. Este auditório será tanto maior, quanto maior for a comunidade de intérpretes ${ }^{132} \mathrm{e}$, nesta mesma razão, maior será também a possibilidade de refutação do argumento.

Neste sentido, então, forçoso é se questionar: em que medida não apenas a democracia, mas, também, a própria comunidade de intérpretes foram, ou não, aperfeiçoadas com o surgimento da televisão e com o papel que esta desempenha na sociedade contemporânea? Apreciar a televisão, em si, e as repercussões trazidas por esta na interpretação e aplicação do princípio da publicidade, quer sob uma perspectiva sociológica, quer sob uma perspectiva psicanalítica, é trabalho do qual o jurista do século XXI não pode se afastar, vez que quanto mais este ignora a repercussão da televisão no contexto social e, por consequência no Direito, mais esta avança sem qualquer contenção ou contrapeso ${ }^{133}$.

Por conseguinte, interpretar o princípio da publicidade (norma) é jamais olvidar a circunstância fática que é manipulada, amplificada, recortada, editada e distorcida pela televisão ${ }^{134}$. "A televisão é uma componente fundamental desta mudança de século porque é um duplo: um componente da era moderna ou da modernidade, que se encerra no século XX, assim como do século XXI, em tempos de pós- 
modernidade" 135 . Negar isto é correr o risco de ser taxado de ingênuo ou de alienado.

\subsection{O PRINCÍPIO DA PUBLICIDADE E A TELEVISÃO}

Convém destacar, assim, que analisar a televisão e suas repercussões em torno da interpretação e aplicação do princípio da publicidade demanda do jurista a cautela de não proceder de forma açodada diante deste fenômeno complexo que é a televisão. A televisão, que deixou de ser a "caixa falante" da década de sessenta do século XX, é, hoje, a "melhor amiga do homem" pós-moderno ${ }^{136}$. Constatar tal fato revela a importância que a televisão desempenha na sociedade contemporânea, entretanto, nada esclarece como e por que este processo aconteceu.

Sendo assim, um estudo sério em torno do princípio da publicidade, seja no que toca ao seu caráter normativo, enquanto realidade complexa, seja no que se refere à sua interpretação e aplicação, demanda do jurista que não proceda a um recorte "caolho" da realidade, ou seja, a um recorte exclusivamente jurídico quer do aludido princípio, quer da sua relação com a televisão. Por conseguinte, examinar o princípio da publicidade requer um estudo aprofundado da televisão, seja por um viés filosófico, seja por um ângulo sociológico, seja, ainda, por uma apreciação psicanalítica.

Por isso, impõe-se se fazer, de logo, a seguinte pergunta: a televisão representa um perigo para a democracia? Esta é a pergunta que motivou Karl Popper e John Condry a se dedicarem em torno do tema ${ }^{137}$. Antes de responder a tal pergunta, convém perceber que o só fato de formular tal indagação já é razão suficiente para que se pense seriamente acerca da interação entre o princípio da publicidade no processo penal e a televisão e as consequências danosas que tal binômio pode ou não propiciar à democracia.

O certo é que a televisão é um fenômeno moderno, afinal, só o século XX e sua "fabulosa civilização" vieram a conviver com este "eletrodoméstico inofensivo". Sendo assim, qualquer análise que se faça em torno da televisão, é sempre um exame que se inicia a partir do século XX. Contudo, se, por um lado, esta circunstância provoca a pouca produção literária em torno do tema, por outro, torna o mesmo matéria de singular relevância, uma vez que é fenômeno típico do 
cotidiano atual, desconhecido das eras passadas e que ocupa grande parte do tempo da rotina diária das pessoas (tudo passa pelo vídeo, o uso das redes bancárias, o uso do computador, os jogos eletrônicos, as salas de bate-papo etc. $)^{138}$. Em suma, o princípio da publicidade no processo penal e sua relação com a televisão são pouco estudados, mas, por outro lado, integram o cotidiano da vida das pessoas, cada vez mais cercada por notícias sobre violência.

Se é impossível negar tais circunstâncias, logo, se conclui que analisar a democracia no mundo pós-moderno e o princípio da publicidade no processo penal requer uma apreciação meticulosa da televisão. A família contemporânea, célula de uma sociedade democrática, marcada por uma nova relação entre capital e trabalho ${ }^{139}$, na qual o tempo foi elevado à condição de valor maior do sistema capitalista, demanda cada vez menos tempo na tarefa de educar seus filhos ${ }^{140}$, ao passo que tal espaço é cada vez mais preenchido pela televisão, a qual tudo sabe e nunca mente ${ }^{141}$, afinal "a televisão sempre diz a verdade" 142.

A televisão, que, antes mais nada, é espetáculo, dedica cada vez mais do seu precioso tempo, dos minutos de sua audiência, à violência, o que leva Giancarlo Bosetti a afirmar que a família da sociedade contemporânea educa os seus filhos para a violência através da televisão e de outros órgãos de comunicaçãa ${ }^{143}$. Aliás, tal circunstância acaba por conduzir Karl Popper, defensor maior do liberalismo e teórico da sociedade aberta, a defender, em nome da democracia, o remédio amargo da censura mitigável. Seja como for, tal raciocínio remete, então, o jurista a ponderar acerca do princípio da liberdade de manifestação do pensamento e da aplicação do princípio da publicidade no âmbito processual penal.

Mas não apenas isto. É preciso refletir sobre os danos infligidos à sociedade por uma expansão incontrolada do poder da televisão, seja em termos de tempo perdido, seja no que toca à influência nefasta que exerce sobre os comportamentos, seja no que tange à concorrência que instaura com a família e com a escola, seja no que diz respeito à distorção do debate público, seja, por fim, no que concerne à inflação desmesurada dos mitos e da "vedetização"144. A compreensão de tais circunstâncias em muito auxilia a entender como o princípio da publicidade no processo penal, em dias atuais, tem sido distorcido por partes das autoridades estatais, nomeadamente certos profissionais 
da polícia, que se aproveitam da televisão para se promoverem perante os seus superiores hierárquicos e a grande população.

Contudo, como a televisão é expressão e manifestação de um princípio de liberdade de imprensa, a tarefa de limitar o seu poder num ambiente democrático não é nada fácil. Seja como for, o fato é que, diante do poder da televisão na sociedade contemporânea, o princípio da publicidade no processo penal não pode continuar a ser interpretado como outrora, ou seja, indiferente às repercussões estigmatizantes produzidas pelo processo e amplificadas pela televisão. Note-se que, se a essência do Estado Democrático de Direito é a não violência, quanto mais a cultura que alimenta este Estado se inspirar no culto à violência, maior será a necessidade de intervenção do Estado sobre a televisão ${ }^{145}$, pois, do contrário, ter-se-á uma sociedade constituída por homicidas ${ }^{146}$.

Com efeito, a televisão, que é obstáculo no caminho que conduz a uma sociedade aberta ${ }^{147}$ e tolerante, é, também, filha do progresso tecnológico e consequência da liberdade ${ }^{148}$. Se é certo que o homem precisa da liberdade para impedir o Estado de abusar de seu poder, e aí se compreende o princípio da publicidade enquanto garantia individual, também é certo que o mesmo necessita do Estado para impedir a liberdade de provocar abusos, no caso, por parte da televisão ${ }^{149}$. É claro que a relação entre o princípio da publicidade no processo penal e a televisão e suas consequências danosas para o cidadão não são problema que possa ser resolvido no plano abstrato por intermédio de leis ${ }^{150}$, mas tarefa que demanda a análise de cada caso. Esta análise poderá implicar, sim, na inevitável restrição da liberdade de imprensa como uma exigência indispensável à coexistência humana.

Insista-se, mais uma vez, a televisão instila a violência no seio da sociedade, promove o espetáculo da guerra dos grandes centros urbanos, o que acaba por produzir perturbações catastróficas no âmago da sociedade. Tais perturbações acabam por provocar a perda da sensibilidade diante da desgraça alheia ${ }^{151}$ e o convívio com o crime. E, mais ainda, a interpenetração desvirtuada entre o princípio da publicidade e a televisão acaba redundando na utilização por parte da mídia da curiosidade humana diante do mórbido (o cadáver decapitado e exposto em via pública, diante do qual todos param para ver), seja despertando o gozo a partir do sofrimento do outro, seja, por fim, 
potencializando a fragmentação social ${ }^{152}$. Triste fim de Policarpo Quaresma ${ }^{153}$.

Releva notar que, em face de a televisão ser uma relativa novidade, bem como em razão da inércia das instituições políticas, incapazes de reagir com rapidez, e da conivência, por exemplo, de algumas autoridades policiais, é que a televisão se tornou um poder incontrolado. Qualquer poder incontrolado contradiz os princípios de democracia ${ }^{154} \mathrm{e}$, por consequência, o princípio da publicidade no processo penal. Mas a televisão não apenas explora a violência, ela também provoca os desequilíbrios da vida política, a corrupção do discurso público, bem como torna cada vez mais difícil captar a diferença entre realidade e ficção ${ }^{155}$, o que acaba por tornar a reflexão ${ }^{156}$ mais profunda acerca desta e de sua relação com o princípio da publicidade uma necessidade de primeira grandeza nos dias de hoje.

Certamente, os defensores da televisão, diante da proposta que aqui se faz por uma nova concepção do princípio da publicidade no processo penal, não hesitarão em afirmar que tal proposta é, em verdade, uma censura camuflada. Mas que os cidadãos mais avisados não se deixem levar por tal blasfêmia, vez que a maior defensora da liberdade é também a maior praticante da verdadeira censura ${ }^{157}$.

Isto mesmo, é a maravilhosa caixa de imagens e sons que mais exercita a censura ${ }^{158} \mathrm{em}$ pleno tempo de democracia, à medida que corta, edita e manipula imagens e falas, à medida que é soberana sobre sua grade de programação, seja para não exibir ou atrasar a apresentação de diálogos e imagens, seja para alocar, em horários de pouquíssima visibilidade (a exemplo dos sábados à noite e das madrugadas dos dias úteis), falas e imagens inoportunas ${ }^{159}$. Ou seja, a televisão destaca ou não os atos praticados pelas autoridades públicas de acordo com a sua conveniência e oportunidade, ou melhor, de acordo com os dividendos que podem the render, desprezando os fatos de relevância cultural, como, por exemplo, a exposição de uma mostra de arte moderna num museu da cidade, e colocando em evidência, com chamadas bombásticas, as notícias referentes aos crimes mais sangrentos e hediondos que aconteceram nas últimas vinte e quatro horas. A busca pela audiência é a maior de todas as censuras.

Ressalte-se, portanto, que a lógica do consumo que permeia os meios de comunicação de massa decreta a produção de "manchetes 
bombásticas" e a comercialização da violência como produto de consumo. Aliás, convém pôr em relevo, com espeque na lição de Jean Baudrillard ${ }^{160}$, que a violência na sociedade do consumo, bem como a conjunção entre o princípio da publicidade no processo penal e a televisão, desempenham diversas funções. A primeira delas é que a grande massa "pacificada" é quotidianamente alimentada pela violência consumida e pela violência alusiva a toda substância apocalíptica do "mass media", como forma de dar vazão à agressividade e ao instinto destrutivo inerente ao ser humano (além do fascínio - poder e prazer - exercido pela morte).

Uma segunda função é a relativa à violência como estratégia para despertar uma obsessão por segurança e bem-estar e provocar uma febre de consumo bélico. Esta, por sua vez, é seguida por uma outra função, a qual põe em destaque a violência "espetacularizada" e o conformismo da vida quotidiana como realidades abstratas que se alimentam de mitos e signos. Uma quarta função é a que ressalta a violência ministrada em "doses homeopáticas" pela mídia como forma de realçar a fragilidade real da vida pacificada, vez que é o espectro da fragilidade que assedia a civilização da abundância, à medida que evidencia o equilíbrio precário que firma a ordem de contradições que constitui a sociedade contemporânea. Note-se, também, que uma outra função é a da violência inexplicada como uma imposição de revisão das ideias de abundância e das taxas de crescimento da economia, face às contradições fundamentais da abundância.

Ademais, cabe, ainda, ressaltar como função a relativa à violência que desperta como consequências, dentre outras, a destrutividade das instituições e a depressividade contagiosa da população, passando por condutas coletivas de fuga (como, por exemplo, o aumento do consumo de drogas ilícitas ou não). Mas não apenas isto. Cumpre destacar a violência que resulta da pulsão desencadeada pelo consumo, o condicionamento do espectador diante do apelo do espetáculo como estratégia de manipulação do desejo. Não fosse isso suficiente, é conveniente, ainda, pôr em evidência a violência que conduz a reabsorção das angústias através da proliferação das terapias, dos tranquilizantes, ou seja, a sociedade de abundância, produtora de satisfação sem finalidade, esgota os recursos a produzir o antídoto para a angústia derivada da satisfação. 
Ao se propor, portanto, um exame acurado da relação imbricada entre o "mundo de plasma" e o princípio da publicidade no processo penal, é preciso despertar para circunstância de que a "deslumbrante caixa de imagens e sons" não foi feita para ser um instrumento de educação em larga escala, afinal, é quase impossível constituir uma grade de programação, todos os dias, durante vinte e quatro horas consecutivas, que apenas exiba programas de bom nível cultural. Aliás, quanto mais numerosas são as emissoras de televisão, mas difícil é encontrar profissionais verdadeiramente capazes de produzir programas, simultaneamente, atraentes e de boa qualidade e mais acirrada tornar-se-á a disputa pela atenção do telespectador. A busca pela audiência e a concorrência entre as emissoras acabam por censurar a informação sobre o caso penal, à medida que essa é padronizada e não reflete nem a inteireza do fato da vida nem ao menos a realidade do processo penal. A diferença na elaboração e divulgação da notícia não é lucrativa.

O que está por detrás dos picos de audiência não é a construção de uma grade de programação de qualidade, mas a manipulação dos instintos humanos, o jogo do lúdico, a lógica do gozo ${ }^{161}$, o estímulo ao desejo, a disponibilização do prazer imediato, a maquiagem da realidade enfadonha. Isto é, a televisão, de um lado, estimula a massa de telespectadores, de outro, fomenta o individualismo e a acomodação das elites intelectuais, podendo-se, assim, falar numa "refeudalização". O que resulta deste fenômeno é que tudo passa a ser extremamente fragmentado, diluído e essas fragmentações ${ }^{162}$ marcam uma grande multiplicidade e difusão de atuações, interferências sem mais nenhum sentido único, geral para todos na sociedade. Não é preciso demandar grande esforço de raciocínio para perceber os sérios riscos que correm a democracia diante de tais circunstâncias e a implicância destas na interpretação e aplicação do princípio da publicidade no processo penal.

A televisão suprime as noções de futuro e passado, inaugurando a ditadura do presente (como nos sonhos e nas representações do inconsciente ${ }^{163}$, situações, pessoas, fatos das mais distintas épocas misturam-se com harmonia num conjunto completamente incoerente ${ }^{164}$ ), que se desdobra a cada dia, como as edições do telejornal que nunca deixam de ir ao ar. O resultado disso é que o telespectador não pensa sobre notícia, mas com a notícia, ou melhor, pensa a partir da 
notícia. $\mathrm{O}$ apresentador (âncora) do telejornal é guindado à qualidade de paladino da justiça, da moral e dos bons costumes. E, pior do que isto, a televisão acaba por manipular o princípio da publicidade no processo penal, de sorte a adestrar as pré-compreensões dos intérpretes sociais.

A televisão, então, além de fiel companheira do telespectador, a preencher o vazio existencial ${ }^{165}$ deixado pelo afastamento do outro ${ }^{166}$, torna-se uma suposta fonte de cultura, à medida que toda informação que dela provém, "além de verdadeira, é neutra de valores, segura e confiável"167. Quando se pensa a partir da notícia, e não sobre esta, tende-se a distorcer o princípio da publicidade no processo penal, vez que se um fato, objeto de um inquérito policial, por exemplo, for habilmente desconstruído nas mesas de edição do estúdio de televisão, esta poderá contar o mesmo fato de diferentes formas, e, certamente, o que irá determinar a maneira como o fato será levado ao "ar" para o grande público não será a busca da verdade, mas, sim, a busca pela maior audiência. Aliás, para que um delito saia do noticiário, é necessário que outro escândalo aconteça.

Portanto, a televisão estabelece um pseudodiálogo ${ }^{168}$ com o cidadão telespectador, ou melhor, o consumidor, formulando o questionamento, investigando as hipóteses, elaborando as justificativas e trazendo uma resposta pronta, fácil e rápido de ser consumida, de sorte que o consumidor não precise pensar. Afinal, pensar demanda tempo, e tempo, na sociedade contemporânea, é dinheiro. Não é preciso pensar, pensar cansa. Por isso, fique tranquilo consumidor, a televisão fará isso por você $\hat{~}^{169}$. Por conseguinte, a televisão inaugura um sistema de adestramento coletivo, reformulando o modelo do panóptico ${ }^{170}$, à medida que se esmera na tarefa diária de vigiar o que cada consumidor pensa, de sorte a lhe "poupar esta árdua tarefa"171.

A reformulação do modelo panóptico agora por meio da televisão, confere um potencial de vigilância e controle fantástico aos fatores reais de poder. Nesse sentido, pode-se dizer que a distorção do princípio da publicidade no processo penal, que vem sendo operada pelas autoridades públicas e pelos meios de comunicação, não se constitui num fracasso perante o sistema punitivo, mas num sucesso retumbante ${ }^{172}$, vez que delimita com muito mais vigor o rol dos excluídos e reforça o estigma que recai sobre eles ${ }^{173}$. Em outras palavras, 
o sistema punitivo encontrou na combinação princípio da publicidade, liberdade incontrolada da imprensa e televisão a ferramenta ideal de reforço e multiplicação de estigmas ${ }^{174}$.

Com efeito, a televisão baseada numa linguagem autorreferencial que tem por escopo criar uma realidade mais real do que a real, um simulacro, no qual a sociedade torna-se um teatro de fantoches. Desabam-se os mitos. A televisão instila uma descrença generalizada, ela que é mosaico de peças eletrônicas, fascínio do telespectador, ao mesmo tempo em que se torna o relógio da sociedade pós-moderna ${ }^{175}$. Os eventos têm seus horários marcados pela televisão, a exemplo da conhecida cena na qual a autoridade policial, diante de todas as câmeras e para todos os flashes, coloca as algemas ${ }^{176}$ no suposto acusado. Eis que, então, a televisão tem uma história para contar, na qual o "mocinho" exibe o "vilão". Por conseguinte, não é demais dizer que a televisão, instrumento aperfeiçoado da barbárie moderna ${ }^{177}$, é, num mesmo instante, ladra do tempo e deformadora da realidade ${ }^{178}$.

A televisão devassa as intimidades, não deixa espaço para os mistérios, não deixa espaço para a imaginação e participação do receptor, ou seja, a linguagem televisiva não é um diálogo, mas um monólogo, ao qual o receptor não é convidado a interferir, mas a consumir. O resultado disso é que a televisão que diz combater a criminalidade e a violência com a divulgação da notícia, em verdade, induz cada vez mais esta por meio da repetição alucinante e neurótica ${ }^{179}$ das mensagens ${ }^{180}$, do discurso incessante e vazio, do prolongamento infinito da história. "A televisão fala o tempo todo e não cessa de falar” ${ }^{\prime 181}$. Aliás, a verborragia, a interminável produção contínua de falas sobre falas faz parte da sintomatologia clínica da esquizofrenia ${ }^{182}$.

Talvez, por isso, Ciro Marcondes Filho assevere que:

É consensual em todas as grandes teorias psicanalíticas da loucura, principalmente a escola norte-americana de Gregory Bateson, a escola francesa de Jacques Lacan e a alemã de Alfred Lorenzer, que o detonador de todos esses processos é o próprio processo da comunicação. No momento em que as pessoas têm acesso à linguagem, ocorre a criação de condições para que, mais tarde, segundo estímulos maiores ou 
menores do ambiente, cresçam sem problemas ou tornem-se patologicamente prejudicadas. A comunicação social em grande escala, para massas imensas de audiência, é apenas um amplificador fantástico de loucuras engendradas em cenas muito mais remotas ${ }^{183}$.

A televisão redesenha os costumes, debocha das tradições e se aproveita do uso comum. Nesse sentido, a televisão, a um só tempo, angustia o homem pós-moderno por meio de uma inflação informativa ${ }^{184}$, o que potencializa a sua sensação de insegurança ${ }^{185}$, bem como torna a sua memória preguiçosa ${ }^{186}$, em razão da sobreposição de imagens e falas que acabam por cultuar o tempo presente. $\mathrm{O}$ homem não se lembra da última novela, do que almoçou ontem, mas apenas do que fez no minuto anterior. Por isso, a televisão se aproveita da solidão e da curiosidade desse homem e dissemina a ideia de que o processo penal deve ser rápido como a sucessão de mensagens publicitárias durante o intervalo comercial. Contudo, a complexidade do caso penal não permite que se tenha um processo penal em trinta segundos, sob pena de se ofender seriamente o princípio do devido processo legal.

Aliás, é arrimado na relação dialética entre os princípios da publicidade no processo penal e do devido processo legal que não se pode permitir o avanço descontrolado do poder da televisão. A televisão de hoje é a arena romana de ontem, ao mesmo tempo em que diverte a massa (no Brasil, em grande parte analfabeta) com a desgraça alheia, permite aos fatores reais de poder manter aquela sob controle por meio de seus instrumentos anestésicos.

Mas a televisão não se contenta com tal estratégia, vale-se, também, da ideia psicanalítica da transferência ${ }^{187}$, no momento em que interage com o princípio da publicidade. Em outros termos, a interpenetração entre a televisão e o princípio da publicidade no processo penal proporciona que o excluído se projete na celebridade e sinta, ainda que instantaneamente, incluído. E, mais ainda, induz o excluído a ver no crime um meio de obter visibilidade, de se tornar celebridade, de se tornar existente para a sociedade. Afinal, Ser, na sociedade pósmoderna, é Ser percebido. E Ser percebido é Ser percebido pela televisão ${ }^{188}$. 
Não é demais dizer, então, que a televisão é "aparelho privado de hegemonia" responsável pela disseminação do pensamento dominante ${ }^{189}$. E esta informação é repetida até o limite do suportável, até que a mensagem viscosa fique impregnada no subconsciente das massas ${ }^{190}$, numa só palavra, a mídia como aparelho privado de hegemonia ${ }^{191}$. Nesse sentido, Venício A. de Lima averba que:

O advento dos meios de comunicação eletrônicos, sobretudo da televisão, transforma a mídia no "aparelho privado de hegemonia" mais eficaz na articulação hegemônica (e contra-hegemônica), vale dizer, na capacidade de construir/definir os limites do hegemônico (da realidade) dentro dos quais ocorre a disputa política ${ }^{192}$.

A televisão concorre com o Congresso Nacional ${ }^{193}$. Em dias atuais, os temas de apelo popular são primeiro discutidos na televisão para, só no momento seguinte, repercutirem nas Casas Legislativas, pode-se falar, assim, numa crise de representatividade e legitimidade do Poder Legislativo, a qual se não é produzida pela televisão, certamente é agravada por essa. Aliás, no mundo pós-moderno, a televisão, ao mesmo tempo em que elege o Presidente da República, fiscaliza a atuação do Poder Judiciário. Note-se, bem, não se afirma aqui que a televisão seja um poder, ou, ainda, que seja possível falar em tripartição de poderes.

O poder é uno e não é a tevê que o encarna, mas é instrumento deste, assim como a religião foi em épocas passadas. Diga-se, desde logo, que não é demasiado afirmar que a televisão intimida o magistrado, vez que agora ela é tanto a Corregedoria, a fiscalizar e punir os juízes autônomos e desobedientes, quanto o Tribunal de segunda instância, a reformar as decisões por ela questionadas. Numa só palavra, a televisão é um formidável instrumento de manutenção da ordem simbólica ${ }^{194}$.

Com efeito, o trabalho da televisão é manejar símbolos, seja para induzir comportamentos junto às massas, seja para entorpecer o indivíduo com a sua dose diária de ilusão necessária à subsistência ${ }^{195}$. Da mesma maneira que a televisão manipula os símbolos, as autoridades policiais, dentre outras, distorcem o princípio da publicidade no inquérito policial, selecionando os casos com potencial 
para a primeira capa do jornal. A boa notícia acerca de um caso penal não é aquela que bem informa, mas aquela por meio da qual o repórter pode buscar seu reconhecimento profissional. Vê-se, desta forma, que o princípio da publicidade ajuda a reescrever as cifras ocultas ${ }^{196}$.

É preciso que se perceba que, quando a imagem da televisão se tornou digital graças aos avanços da tecnologia, isto acabou por conferir a esta um conjunto de possibilidades infinitas para a manipulação das mensagens transmitidas, vez que a imagem passa a ser uma sequência de pontos, conversíveis em números. Não é por outra razão que Edmund Couchot assevera que "a imagem numérica não é mais a transposição de um modelo determinado, não é mais a reprodução mais ou menos exata de um original, uma duplicata óptico-química como a fotografia, é uma imagem com possibilidades infinitas" ${ }^{\text {"197. A }}$ televisão torna-se, assim, um instrumento ainda mais perigoso a serviço do poder $^{198}$.

As imagens da televisão nunca são mudas, de sorte a permitir a interpretação do receptor, são sempre acompanhadas por uma voz ao fundo, a qual se encarrega de guiar a interpretação. Mas não apenas isto. A imagem sempre está em close, de sorte que o telespectador apenas veja o que foi selecionado, sem que tenha a possibilidade de perceber o que não foi enquadrado. Disto resulta que a televisão não democratiza a informação proporcionada pelo princípio da publicidade dos atos das autoridades públicas, pelo contrário, seleciona um fragmento dos fatos e o divulga como se fosse o próprio fato. Pode-se dizer, assim, que o close da imagem televisiva e a síntese da complexidade do caso penal são instrumentos da seletividade do sistema punitivo e mecanismos inviabilizadores do exercício pleno da ampla defesa. O que dizer dos casos de apelo popular (Caso Isabela Nardoni ${ }^{199}$, Caso Suzane von Richthofen ${ }^{200}$, Caso João Hélio ${ }^{201}$, dentre outros) levados ao Tribunal do Júri, após semanas de massificação da mensagem de condenação pela mídia?

Portanto, não é possível falar de uma televisão realmente interativa, a interatividade é uma aparência, um discurso, mas não uma "realidade". Em outros termos, a interatividade é uma estratégia aprimorada da televisão a serviço dos fatores reais de poder, de sorte a preservar a hegemonia desse último e a manter os excluídos em exclusão. A tevê, 
por conseguinte, não exibe o excluído, somente o faz quando visa reforçar essa qualidade.

Mais do que isso, a interatividade possui um diferencial ainda mais pernicioso, os excluídos, por meio dela, sentem-se, ainda que instantaneamente, incluídos. Quando a televisão leva ao público as suas manchetes, ela parece incluir a todos os telespectadores, levando aos receptores a mesma informação. Todavia, trata-se apenas de uma aparência, pois enquanto os excluídos não foram convidados a elaborar a notícia, aqueles que se encontram no poder interferem diretamente na produção daquela ${ }^{202}$.

Destaque-se, mais uma vez, a linguagem da televisão é marcada por uma pulsação, por meio da qual, conforme destaca Umberto Eco, ela não transmite fatos, mas produz esses ${ }^{203}$. Ela não divulga crimes, ela explora esses. Nas palavras de Arthur Kroker, "na cultura pósmoderna, não é a tevê que é o espelho da sociedade, mas exatamente ao contrário: é a sociedade que é o espelho da tevê" ${ }^{204}$. Talvez por conta dessa constatação, Marshall McLuhan tenha asseverado que a televisão não é um "meio frio" ${ }^{205}$ como o rádio ou o jornal, vez que ela não apenas manipula os sentidos da visão e audição, ela tenta ser o "mundo todo" 206.

Veja-se, desta forma, que a tevê é narcísea, e disto resulta que, agora, ela não tem mais qualquer compromisso com a verdade e com os fatos, ela olha para si mesma, fala de si mesma, ela é o próprio mundo ${ }^{207}$. Se a televisão não tem compromisso com os fatos, mas com a audiência, por que ela teria compromisso com a garantia individual do princípio da publicidade? A televisão é, portanto, veículo de ideologia que se empenha, dia após dia, para sufocar as ideologias rivais ${ }^{208}$. Numa só palavra, as câmeras de hoje são as fogueiras da inquisição de ontem, queimam muitos inocentes, a custa de alguns culpados.

Logo, a televisão não emite a "opinião pública", se é que isso existe, ela fabrica e propala a sua opinião, à medida que se autoelege representante dos interesses da sociedade, ao mesmo tempo em que a mobiliza. Resta a pergunta: quem lhe conferiu tais poderes? Em razão dos limites do presente trabalho, não irá se especular aqui em torno das possíveis respostas à referida pergunta. O certo é que a tevê não é um poder, mas um dos melhores instrumentos dele. Aliás, é em razão disso, não se perca de vista, que a “opinião publicada”, em regra, insufla 
o confronto direto entre os cidadãos como estratégia ideal de encobrimento das falhas do Estado, seja promovendo linchamentos públicos, seja elegendo um determinado "delinquente" como o inimigo número um da população.

Diga-se, por mais uma vez, que a televisão guia a atividade das autoridades públicas. O que dizer do juiz que interroga os acusados diante das câmeras? O que dizer do juiz que decreta uma prisão preventiva em nome da ordem pública ${ }^{209}$ ? Note-se, assim, que, à medida que o tempo passa, a combinação perniciosa entre o princípio da publicidade no processo penal e a televisão produz cada vez mais efeitos nocivos (por exemplo, destrói a imagem e a honra do acusado). E, se o estigma causado ao suposto autor do delito é um deles, o comprometimento dos princípios da imparcialidade e do sistema acusatório, no que toca ao último exemplo acima mencionado, é, sem dúvida, um outro.

Seja como for, constatar tal fato, por si só, permite perceber não só a relação que o princípio da publicidade mantém com a televisão, bem como o enlace entre aquele e uma sensação disseminada pela sociedade pós-moderna: a sensação de insegurança.

\subsection{O PRINCIPIO DA PUBLICIDADE E A SENSAÇÃO DE INSEGURANÇA}

Parafraseando Bauman ${ }^{210}$, pode-se dizer que o mal-estar da pósmodernidade, pelo menos no Brasil, se é que realmente se pode falar em pós-modernidade em terras tupiniquins, é o mal-estar, ou melhor, a sensação de insegurança. À medida que a televisão repete até a exaustão as mensagens sobre violência a partir da publicidade dos atos das autoridades públicas, dissemina-se, cada vez em maior escala, a sensação de insegurança.

Note-se que a sensação de insegurança é o elemento motivador pela busca incessante por cada vez mais notícia que tenha por objeto a violência. É essa sensação que fomenta a procura por mais informação em torno da violência, apesar da oferta diária e excessiva dessa. Ou seja, a sensação de insegurança inverte a lógica econômica da procura e da oferta e, nesta medida, torna-se um excelente instrumento lucrativo para aqueles que se lambuzam na combinação fétida entre a 
incapacidade do aparelho estatal e a exploração da desgraça alheia. $O$ que dizer da televisão, ou, ainda, das empresas de segurança privada?

Mas não apenas isso. A crescente sensação de insegurança desnorteia a racionalidade do cidadão, à medida que este consente com a barbárie praticada pelos órgãos do Estado, notadamente a polícia. Ou seja, o cidadão não se revolta diante da cena na qual o policial atira "pelas costas" de um preso provisório que tenta fugir da "casa dos horrores" que é a prisão. Mais que isso, o cidadão não se sensibiliza diante da tortura diária das celas superlotadas. É como se a opinião publicada estivesse levando o cidadão a entender que aquele que não colabora com o Estado é conivente com a "marginalidade". O homem se esquece de sua dignidade humana.

É, ainda, esta crescente sensação de insegurança que desnorteia a racionalidade da opinião publicada, que fomenta o culto à segurança. Acredita-se na existência de uma segurança. Ora, a segurança é em si um mito, tanto porque, no que toca à sua abordagem fenomenológica, esta é fundamentalmente uma sensação, quanto porque, no que toca ao seu aspecto simbólico, essa tem a pretensão (se tem capacidade de proporcionar o fim a que se propõe, isso é bastante duvidoso) utilitária de proporcionar determinados fins, quais sejam, econômicos (principalmente), políticos e psicológicos, dentre outros, todos eles eivados de conteúdo ideológico ${ }^{211}$. Enquanto mito ${ }^{212}$ que é, a segurança não é um dado, nem admite demonstração, é um objeto de fé, para uns, e de manipulação e venda, para outros.

Contudo, o homem pós-moderno não se apercebe de que a mesma informação que lhe traz um momento de segurança será aquela que lhe propiciará, num instante seguinte, um estado de insegurança. Consome-se informação não porque o mundo globalizado esteja orientado por valores altruístas educacionais. Consome-se porque é preciso consumir, porque o consumo é a razão, é o próprio Ser (Deisen) do mundo pós-moderno. À medida que se consome, o homem é levado a consumir mais. Todavia, à medida que se consomem novas informações, outras são massificadas, e estas novas informações aumentam a probabilidade de refutação do conhecimento, das "ciências", das "verdades" físicas, da segurança, o que provoca no homem uma crise de abstinência informativa e o leva a novamente consumir. 
A interação nociva entre o princípio da publicidade no processo penal, a liberdade de imprensa, a televisão e a sensação de insegurança, acabam por inculcar no inconsciente coletivo que agora o inimigo não tem mais rosto. Isto mesmo, o inimigo não usa farda, não é identificável e é muito bem camuflado. Ele anda entre os cidadãos e pode ser um deles. O inimigo muitas vezes é o próprio Estado e a sua polícia. No Rio de Janeiro, por exemplo, a polícia mata mais do que aqueles ditos à "margem da lei" 113 . Já não se sabe quem é o "mocinho ou o vilão", quem é a "polícia ou o ladrão". Numa sociedade que depende de heróis, esse é o problema em se tentar identificar o inimigo: morre mais um inocente à custa de um suposto "bandido".

O fruto dessa combinação explosiva entre princípio da publicidade, liberdade de imprensa e televisão é que, como a própria mídia em matéria relativamente recente divulgou, a sensação de insegurança no Brasil é a maior do mundo, diz $\mathrm{ONU}^{214}$ :

A sensação de insegurança atinge $70 \%$ dos brasileiros e é a maior do mundo, segundo relatório divulgado nesta segunda-feira pela Organização das Nações Unidas (ONU). A estatística faz parte do Relatório Global sobre Assentamentos Humanos, do Programa das Nações Unidas para Assentamentos Urbanos (UN-Habitat), que este ano aborda o tema da segurança em várias cidades do planeta. O relatório também mostra que a cidade de São Paulo responde por 1\% de todos os homicídios do planeta - apesar de ter apenas 0,17\% da população mundial. De acordo com o coordenador de análise e planejamento da Secretaria de Segurança Pública de São Paulo, Túlio Khan, a violência no Estado está diretamente relacionada com o uso de bebidas alcoólicas e o porte de arma de fogo.

Segundo o relatório, no Rio de Janeiro os índices de homicídios triplicaram desde a década de 70, enquanto que em São Paulo o número quadruplicou. No Brasil, mais de 100 pessoas são mortas por armas de fogo todos os dias, sendo 
que no Rio de Janeiro a taxa de mortes por armas é maior que o dobro da média nacional. De acordo com a ONU, a guerra entre traficantes, a invasão policial e a alta densidade populacional pioram a qualidade de vida nas favelas. Rio e São Paulo registram mais da metade dos crimes violentos no país.

O estudo da ONU também mosta que crime está crescendo assustadoramente em grandes aglomerados urbanos na América Latina - onde 80\% das população vive em cidades - e na África onde $40 \%$ da população não está nos campos.

Sobre o Brasil, o levantamento também aponta que existem 35 mil automóveis blindados no país, e que entre $40 \%$ e $70 \%$ da população das principais cidades vivem em assentamentos irregulares.

O relatório mostra que as taxas de crime em nível global e regional cresceram constantemente entre 1980 e 2000, aumentando cerca de $30 \%$, ou seja, de 2.300 para mais de 3.000 por 100 mil pessoas. Crimes violentos, em particular, estão aumentando.

Enquanto as taxas de crime pessoal variam significativamente entre regiões e países, foi estimado que $60 \%$ do total de moradores de locais urbanos dos países em desenvolvimento foram vítimas de crimes. Na América Latina e na África, essas taxas chegam a até $70 \%$.

A estatística confirma que a cultura do medo do crime e da violência está enraizada na maioria dos países. A pesquisa foi feita em cidades de 35 países desenvolvidos e em desenvolvimento. Os entrevistados responderam à pergunta: sentem-se seguros quando voltam para casa à noite? Os índices mais elevados de medo vieram do Brasil $(70 \%)$ e o menor índice foi da Índia (13\%). Os dez primeiros lugares estão divididos entre países da África (4\%) e da América Latina (6\%). 
O documento ressaltou que o rápido processo de urbanização da cidade resultou no aumento de criminalidade, destacando que em 1999 São Paulo registrou 11.455 assassinatos, 17 vezes mais que Nova York, com 667.

Os números do medo do crime (que é diferente da percepção e reconhecimento da iminência do crime) estão associados à violência da polícia, à sensação de insegurança e aos registros oficiais de violência e mortes, assuntos frequentes nos jornais e noticiários.

Diante do exposto é preciso repensar esta relação complexa e manipulada que tem sido, até então, a interação entre o princípio da publicidade no processo penal, a liberdade de imprensa e a televisão. Não porque esta seja a única saída para a crescente sensação de insegurança, ou porque se constitua no caminho que leva ao pote de ouro atrás do arco-íris. Mas porque se revela na estratégia mais consciente e racional possível. É preciso que se pare de "brincar" com a segurança pública, que se contenha o avanço desmedido da televisão, que se puna severamente as autoridades públicas que desvirtuam o princípio da publicidade no processo penal à custa de seu próprio benefício e, por fim, que sejam adotadas políticas de segurança pública racionais e civilizadas, do contrário, logo-logo, não se terá mais do que se proteger, pois já se estará morto.

\section{CONCLUSÃO}

Diante do exposto, o princípio da publicidade no processo penal, face ao papel desempenhado pela televisão na sociedade contemporânea, necessita ser repensado. E repensar tal princípio demanda uma séria reflexão crítica acerca das repercussões criminológicas que a interpretação e aplicação de tal princípio acabam por ocasionar ao suposto autor do delito. Poder-se-ia atribuir tal desvirtuamento a um ranço positivista entranhado no espírito das autoridades públicas proveniente da racionalidade moderna. 
Mas se tal explicação não é absurda, certamente é ingênua, à medida que se presta a encobrir o verdadeiro motivo do desvirtuamento do princípio da publicidade no processo penal pelas autoridades públicas, qual seja, a manutenção do status quo. Em outras palavras, a manipulação do princípio da publicidade no processo penal é uma estratégia de hegemonia. Tal estratégia é aprimorada por meio da televisão, à medida que se multiplicam os segregados e estes são mantidos sob controle.

Portanto, uma nova concepção do princípio da publicidade no processo penal é, antes de mais nada, uma concepção atenta da interpenetração que este hoje mantém com a liberdade de imprensa, a televisão e a sensação de insegurança. Esta nova concepção que aqui se propõe terá tanto mais êxitos quanto maior for a sua vinculação à compreensão do caso penal como um topoi a ser resolvido por meio da argumentação. Não se pode mais admitir a interpretação e aplicação do princípio da publicidade no processo penal de forma alienada à realidade, ou seja, de maneira descomprometida com a ponderação dos valores que se encontram em jogo. Um processo penal que não respeita o problema trazido ao seu conhecimento é um processo penal falido.

\footnotetext{
Notas

${ }^{1}$ Norma compreendida como fruto da interpretação resultante da combinação do texto legal com o fato da vida e que se subdivide em duas espécies, são elas: regras e princípios. Nesse sentido, entre nós, GRAU, Eros Roberto. Ensaio e discurso sobre a interpretação/aplicação do direito. $4^{\mathrm{a}}$ ed. São Paulo: Malheiros, 2006. p. 170-205.

2 O vocábulo "evolução" pode ser compreendido sob diversos enfoques que se adote acerca da história, são eles, dentre outros: o linear, o circular e o helicoidal. A concepção linear sustenta que a história é uma linha em constante progresso acumulativo, a qual nunca experimenta retrocessos. A abordagem circular sufraga a tese de que a história um cíclica, marcada por avanços e retrocessos. E, por fim, a proposta helicoidal, defende que a história é uma linha evolutiva cíclica que admite avanços e retrocessos, havendo uma preponderância daqueles sobre esses. Disso resulta que os vocábulos evolução e/ou progresso, demandam cautela, vez que a opção por qualquer uma das vertentes de história mencionada é sempre, em última análise, uma opção ideológica. Desta circunstância, tanto o jurista quanto o operador do Direito devem ter consciência. Nesse sentido, consulte-se: MORRISON, Wayne. Filosofia do direito - Dos gregos ao pós-modernismo. Tradução Jefferson Luiz Camargo. São Paulo: Martins Fontes, 2006, p. 193-324. Consulte-se, ainda, KÜHN, Thomas. A estrutura das revoluções científicas. $3^{\mathrm{a}}$ ed. São Paulo: Perspectiva, 1991.

${ }^{3} \mathrm{CF}$, Artigo $5^{\circ}$. LX - "a lei só poderá restringir a publicidade dos atos processuais quando a defesa da intimidade ou o interesse social o exigirem".

${ }^{4}$ Cf. SANTOS, Boaventura de Sousa. Introdução a uma ciência pós-moderna. $4^{a}$ ed. Rio de Janeiro: Graal, 1989, p.121-128.
} 
${ }^{5}$ A velocidade como o tempo do lucro da sociedade capitalista. Note-se, assim que a revolução dos sistemas de comunicação atua no tempo e no espaço fazendo-os adquirir novos valores, adaptados à modernidade tardia. $\mathrm{O}$ tempo, que, na sua gênese é uma convenção humana, cada vez deixa mais clara a sua proporção de feitor do homem. $\mathrm{Ou}$ seja, o tempo na sociedade pós-moderna não é o tempo da contemplação, mas o tempo da comunicação, ou, por que não dizer, o tempo da angústia, da produção. Cria-se o tempo interrompido, rapidinho, descontinuando tudo, impondo a adivinhação do resto.

${ }^{6}$ GRAU, Eros Roberto. A ordem econômica na Constituição de 1988. 6ª ed. São Paulo: Malheiros, 2001, p. 40.

${ }^{7}$ BASTOS, Celso Ribeiro. $O$ abuso do poder econômico e o projeto de lei n ${ }^{\circ}$ 3.712. São Paulo: Max Limonad. Revista do Programa de Pós-Graduação em Direito da PUC/SP, 1995, p. 13. FARIA, José Eduardo (Org.). Direito e globalizaçãa econômica: implicações e perspectivas. São Paulo: Malheiros, 1996, p. 48.

${ }^{8}$ FERRAZ JR., Tércio Sampaio. Introdução ao estudo do direito: técnica, decisão e dominação. São Paulo: Atlas, 2007, p. 138.

${ }^{9}$ AZEVÊDO, Bernardo Montalvão Varjão de. A importância dos atos de comunicação para o processo penal: o esboço de uma teoria geral e uma análise descritiva. Rio de Janeiro: Lumen Juris, 2008, p. 12-32.

${ }^{10}$ Note-se, assim, com espeque na lição de Tobias Barreto, que o Direito é um produto da cultura bumana. Por conseguinte, ele não é uma entidade metafísica, superior e anterior ao homem, mas sim produto do desenvolvimento histórico. O direito é, pois, uma disciplina social, portanto, nenhum instituto jurídico, por mais elevado que seja na escala evolucional, deixa de carregar consigo um caráter finalístico. Sendo assim, "o direito é um instituto humano; é um dos modos de vida social, a vida pela coação, até onde não é possível a vida pelo amor; o que fez Savigny dizer que a necessidade e a existência do direito são uma conseqüência da imperfeição do nosso Estado". BARRETO, Tobias. Introdução do estudo do direito - política brasileira. São Paulo: Landy Editora, 2001, pp. 31-36.

${ }^{11}$ LYOTARD, Jean-François. A condição-pós moderna. Tradução: Wilmar do Valle Barbosa. Rio de Janeiro: Editora José Olympio, 2006, p. 80.

${ }^{12}$ MARCUSE, Herbert. Ideologia da sociedade industrial. $3^{\mathrm{a}}$ ed. Rio de Janeiro: Zahar Editores, 1969. De acordo com o autor, todo pensamento das sociedades industriais avançadas, nesse sentido, seria pautado por uma imediaticidade que racionalizava o irracional.

${ }^{13}$ BAUDRILLARD, Jean. A sociedade de consumo. Lisboa: 70 Arte \& Comunicação, 2007.

${ }^{14}$ BOURDIEU, Pierre. La distincion - criterio y bases sociales del gusto. Madrid: Taurus, 2000, p.323.

${ }^{15}$ BAUMAN. Zygmunt. Modernidade líquida. Tradução: Plínio Dentzien. Rio de Janeiro: Jorge Zahar Editor, 1999, p. 46.

${ }^{16}$ BAUMAN. Zygmunt. Identidade. Tradução: Plínio Dentzien. Rio de Janeiro: Jorge Zahar Editor, 2005, p. 35.

${ }^{17}$ ADEODATO, João Maurício. Filosofia do direito - Uma crítica à verdade na ética e na ciência. $3^{\text {a }}$ ed. São Paulo: Saraiva, 2007.

${ }^{18}$ BAUMAN. Zygmunt. O mal-estar da pós-modernidade. Tradução: Mauro Gama, Claudia Martinelli Gama. Rio de Janeiro: Jorge Zahar Editor, 1998, p. 52. CASTORIADIS, Cornelius. A instituição imaginária da sociedade. Florianópolis: Paz e Terra, 2007.

${ }^{19}$ MORRISON, Wayne. Filosofia do direito - Dos gregos ao pós-modernismo. Tradução Jefferson Luiz Camargo. São Paulo: Martins Fontes, 2006, p. 157.

${ }^{20}$ RORTY, Richard. Contingência, ironia e solidariedade. Tradução: Vera Ribeiro. São Paulo: Martins Fontes, 2007, p. 133.

${ }^{21}$ BAUDRILLARD, Jean. Simulacros e simulação. Tradução: Maria João Pereira. Lisboa: Relógio D’água, 1997, p. 27. 
${ }^{22}$ Note-se que, em certa medida o eidos pode ser compreendido como o prenúncio da ambivalência e liquidez que marcam o conhecimento peculiar à pos-modernidade, que nem é binário, nem conciliatório, mas que busca suplantar esta cisão artificial. Nesse sentido, Boaventura de Souza Santos preleciona que a "ciência pós-moderna sabe que nenhuma forma de conhecimento é, em si mesma, racional; só a configuração de todas elas é racional. Tenta, pois, dialogar com outras formas de conhecimento deixando-se penetrar por elas. A mais importante de todas é o conhecimento do senso comum, o conhecimento vulgar e prático com que no quotidiano orientamos as nossas acções e damos sentido a nossa vida. A ciência moderna construiu-se contra o senso comum que considerou superficial, ilusório e falso. A ciência pós-moderna procura reabilitar o senso comum por reconhecer nesta forma de conhecimento algumas virtualidades para enriquecer a nossa relação com o mundo". Consulte-se, SANTOS, Boaventura de Sousa. Um discurso sobre as ciências. $4^{2}$ ed. São Paulo: Cortez, 2006, p. 88-89.

${ }^{23}$ GRAU, Eros Roberto. Ensaio e discurso sobre a interpretação/ aplicaşão do direito. $4^{a}$ ed. São Paulo: Malheiros, 2006. p. 87.

${ }^{24}$ GRAU, Eros Roberto. Ensaio e discurso sobre a interpretậão/ aplicação do direito. $4^{a}$ ed. São Paulo: Malheiros, 2006. p. 184.

${ }^{25}$ NETO, Manoel Jorge e Silva. Curso de direito constitucional. $6^{a}$ edição. Rio de Janeiro: Lúmen Júris, 2007, p. 125.

${ }^{26}$ LASSALE, Ferdinand. A essência da Constituição. $6^{a}$ ed. Rio de Janeiro: Lumen Juris, 2001.

${ }^{27}$ CANARIS, Claus-Wilhelm. Pensamento sistemático e conceito de sistema na ciência do direito. $3^{\text {a }}$ edição. Lisboa: Fundação Calouste Gulbenkian, pp. 9-24.

${ }^{28}$ Quando trata da abertura do sistema, Canaris sustenta que o sistema é aberto quer quanto sistema científico, quer quanto sistema objetivo. Enquanto sistema científico, o sistema é aberto em razão da incompleitude do conbecimento cientifico, ao passo que, enquanto sistema objetivo, o sistema é aberto em razão da modificabilidade dos valores fundamentais da ordem jurídica. Note-se que a abertura do sistema desempenha um importante significado para as possibilidades do pensamento sistemático e para a formação do sistema na Ciência do Direito. Ademais, convém destacar que há uma relação entre as modificações do sistema objetivo e as modificações do sistema científico. A modificação do sistema objetivo implica modificação no sistema científico, mas a recíproca não é verdadeira. Sendo também importante salientar que a modificação do sistema científico não é uma característica peculiar do sistema jurídico, ao passo que a modificação do sistema objetivo é uma característica própria desse sistema.

${ }^{29}$ Convém salientar, assim, que o que se entende por natureza aberta é a combinação da incompletude do conhecimento científico com a modificabilidade dos valores fundamentais da ordem jurídica e, por natureza mutável, a conjugação de igualdade fundamental de categoria, mútua substituibilidade dos critérios adequados de justiça e renúncia simultânea à formação de previsões normativas fechadas.

${ }^{30}$ FERRAZ JR. Tércio Sampaio. Introdução ao estudo do direito: técnica, decisão e dominação. São Paulo: Atlas, 2007, p. 233-246.

${ }^{31}$ MÜLLER, Friedrich. Métodos de trabalho do direito constitucional. Tradução: Peter Naumann. $2^{\mathrm{a}}$ edição. São Paulo: Max Limonad, 2000, p.70-96.

${ }^{32}$ GADAMER, Hans-Georg. Verdade e método I: traços fundamentais de uma bermenêutica filosófica. Tradução: Flávio Paulo Meurer. $7^{a}$ ed. Petrópolis: Vozes - Universidade São Francisco, 2005. p. 354-405.

${ }^{33}$ CANOTILHO, José Joaquim Gomes; MOREIRA, Vital. Constituição da República Portuguesa anotada. Volume I. $1^{\text {a }}$ edição brasileira. São Paulo: RT e Coimbra Editora, 2007, p.577.

${ }^{34}$ BAZDRESCH, Luiz. Curso elementar de garantias constitucionale. México: Editorial Jus, 1977, p. $120-132$. 
35 Acerca da distinção entre direitos e garantias e as dificuldades acerca do tema, consultese AZEVÊDO, Bernardo Montalvão Varjão de. Uma reflexão acerca dos pactos e convenções internacionais e sua aplicação no ordenamento jurídico pátrio. Revista de direito constitucional e internacional. v. 43. São Paulo: RT, 2003, p. 31-48.

${ }^{36}$ CANOTILHO, José Joaquim Gomes; MOREIRA, Vital. Constituição da República Portuguesa anotada. Volume I. $1^{\text {a }}$ edição brasileira. São Paulo: RT e Coimbra Editora, 2007, p. 577-595.

37 Título II, Capítulo I da Constituição de 1988.

${ }^{38}$ MIRANDA, Jorge. Teoria do estado e da constituição. Coimbra: Coimbra Editora, 2005, pp.88/ 89.

${ }^{39}$ CANOTILHO, José Joaquim Gomes; MOREIRA, Vital. Constituição da República Portuguesa anotada. Volume I. $1^{\text {a }}$ edição brasileira. São Paulo: RT e Coimbra Editora, 2007, p.577-595.

${ }^{40}$ FREUD, Sigmund. Totem e tabu. Volume XIII. Tradução: Órizon Carneiro Muniz. $2^{\mathrm{a}}$ ed. Rio de Janeiro: Imago Editora, 1995.

${ }^{41}$ FREUD, Sigmund. O futuro de uma ilusão/O mal-estar na civilização. Volume XXI. Tradução: Órizon Carneiro Muniz. $2^{a}$ ed. Rio de Janeiro: Imago Editora, 1999.

${ }^{42}$ SARTRE, Jean-Paul. Freud, além da alma. Tradução: Jorge Laclette. Rio de Janeiro: Editora Nova Fronteira, 1986.

${ }^{43}$ FREUD, Sigmund. Ob. cit., p. 57.

${ }^{44}$ FOUCAULT, Michel. Microfísica do poder. Rio de Janeiro: Graal, 1979.

${ }^{45}$ FREUD, Sigmund. Ob. cit., p. 78.

${ }^{46}$ BENJAMIN, Walter. Para uma crítica de la violencia. Disponível em: http:// http:// www.ddooss.org/articulos/textos/walter_benjamin.pdf. Acesso em: 20.05.2008.

${ }^{47}$ MORIN, Edgar. Breve bistoria de la barbárie em ocidente. Buenos Aires: Paidos, 2007, p. 33-46.

${ }^{48}$ FREUD, Sigmund. O futuro de uma ilusão/O mal-estar na civilização. Volume XXI. Tradução: Órizon Carneiro Muniz. $2^{a}$ ed. Rio de Janeiro: Imago Editora, 1999, p. 25-32.

${ }^{49}$ LYOTARD, Jean-François. Lo inhumano: charlas sobre el tiempo. Buenos Aires: Manantial, 1998, p. 23-36.

${ }^{50}$ FREUD, Sigmund. Ob. cit., p. 82-83.

${ }^{51}$ SHAKESPEARE, William. Hamlet. Tradução: Jean Melville. São Paulo: Martin Claret, 2003, p. 23-24.

${ }^{52}$ Nesse passo, Karl Popper, lecionando sobre o conhecimento e a ignorância, assevera que "se é possível dizer que a ciência, ou o conhecimento, "começa" por algo, [...] o conhecimento não começa de percepções ou observações ou de coleção de fatos ou números, porém, começa, mais propriamente, de problemas. Poder-se-ia dizer: não há nenhum conhecimento sem problemas; mas, também, não há nenhum problema sem conhecimento. Mas isto significa que o conhecimento começa da tensão entre conhecimento e ignorância. [...] não há nenhum problema sem conhecimento; [...] não há nenhum problema sem ignorância. [...] cada problema surge da descoberta de que algo não está em ordem com nosso suposto conhecimento; descoberta de uma contradição interna entre nosso suposto conhecimento e os fatos [...]". Consulte-se POPPER, Karl. Lógica das ciências sociais. Tradução: Estevão de Rezende Martins, Apio Cláudio Muniz, Vilma de Oliveira Moraes e Silva. $3^{\text {a }}$ ed. Rio de Janeiro: Tempo Brasileiro, 2004, p. 14-15. ${ }^{53}$ BARATTA, Alessandro. Criminologia crítica e crítica do direito penal - Introdução à sociologia do direito penal. Trad. Juarez Cirino dos Santos, Rio de Janeiro: Freitas Bastos Editora, 1999; ANIYAR DE CASTRO, Lola. Criminologia da reação social. Trad. E. Kosowski, Rio de Janeiro: Forense, 1983.

${ }^{54}$ STRECK, Lenio Luiz. Tribunal do júri - Simbolos e rituais. Porto Alegre: Livraria do Advogado, 2001, 159

${ }^{55} \mathrm{O}$ meio de comunicação antecipa-se ao real, através de seus mecanismos, e este vem como uma espécie de "efeito tardio" de sua transmissão. O real passa a ser uma espécie de confirmação daquilo que ficticiamente havia sido apresentado na televisão; busca sua 
afirmação copiando a ficção, tentando ser simulacro de si mesmo. BAUDRILLARD, Jean. Simulacros e simulação. Tradução: Maria João Pereira. Lisboa: Relógio D’água, 1997, p. 27-39. ${ }^{56}$ FREUD, Sigmund. Ob. cit., p. 77.

${ }^{57}$ BAUMAN. Zygmunt. Modernidade líquida. Tradução: Plínio Dentzien. Rio de Janeiro: Jorge Zahar Editor, 1999, p. 71.

${ }^{58}$ BAUDRILLARD, Jean. A sociedade de consumo. Lisboa: 70 Arte \& Comunicação, 2007, p. 6567.

${ }^{59}$ BAUDRILLARD, Jean. A sociedade de consumo. Lisboa: 70 Arte \& Comunicação, 2007, p. 7578.

${ }^{60}$ FREUD, Sigmund. Ob.cit. p. 56-57.

${ }^{61}$ FOUCAULT, Michel. Os anormais. São Paulo: Martins Fontes, 2002, p.48-53.

${ }^{62}$ FREUD, Sigmund. Ob. cit., p. 47-51.

${ }^{63}$ FREUD, Sigmund. Ob. cit., p. 58.

${ }^{64}$ FREUD, Sigmund. Ob. cit., p. 62.

${ }^{65}$ SIMMEL, Georg. Filosofia do amor. São Paulo: Martins Fontes, 2006.

${ }^{66}$ FREUD, Sigmund. Ob. cit., p. 79.

${ }^{67}$ BAUMAN. Zygmunt. O mal-estar da pós-modernidade. Tradução: Mauro Gama, Claudia Martinelli Gama. Rio de Janeiro: Jorge Zahar Editor, 1998, p.18.

${ }^{68}$ FREUD, Sigmund. Ob.cit., p. 80.

${ }^{69}$ FREUD, Sigmund. Ob. cit., p. 83.

${ }^{70}$ FREUD, Sigmund. Ob. cit., p. 83.

${ }^{71}$ ANDRADE, Jose Helder de Souza. Segurança X sensação de segurança. São Paulo: Ciência Moderna, 2002.

${ }^{72}$ FREUD, Sigmund. Totem e tabu. Volume XIII. Tradução: Órizon Carneiro Muniz. $2^{\mathrm{a}}$ ed. Rio de Janeiro: Imago Editora, 1995, p. 64.

${ }^{73}$ FOUCAULT, Michel. Vigiar e punir. Petrópolis: Vozes, 2003, p. 45-57.

${ }^{74}$ PASUKANIS, Eugeni B. Teoría general del derecho y marxismo. Trad. Virgílio Zapatero, Barcelona: Labor, 1976.

${ }^{75}$ BAUMAN. Zygmunt. Modernidade líquida. Tradução: Plínio Dentzien. Rio de Janeiro: Jorge Zahar Editor, 1999, p. 52.

${ }^{76}$ FREUD, Sigmund. Ob. cit. p. 87.

${ }^{77}$ AZEVÊDO, Bernardo Montalvão Varjão de. O amor como fundamento legitimador do direito. Revista Forense. V. 383. Rio de Janeiro: Forense, 2006, p. 489-495.

${ }^{78}$ CHAUÍ, Marilena. Conformismo e resistência - aspectos da cultura popular do Brasil. São Paulo: Editora Brasiliense, 1986.

${ }^{79}$ LYOTARD, Jean-François. Lo inbumano: charlas sobre el tiempo. Buenos Aires: Manantial, 1998, p. 39-42.

${ }^{80}$ FILHO, Ciro Marcondes. Televisão. São Paulo: Editora Scipione, 1994.

${ }^{81}$ FREUD, Sigmund. Ob. cit., p. 47-51.

${ }^{82}$ LACAN, Jacques. Televisão. Tradução: Antonio Quinet. Rio de Janeiro: Jorge Zahar Editor, 1993, p. 32.

${ }^{83}$ MAFFESOLI, Michel. Notas sobre a pós-modernidade - O lugar faz o elo. São Paulo: Atlântica Editora, 2004, p. 35.

${ }^{84}$ LEVY, Pierre. Cibercultura. São Paulo: Editora 34, 1999.

${ }^{85}$ FREUD, Sigmund. Ob. cit., p. 72.

${ }^{86}$ FREUD, Sigmund. Ob. cit., p. 73.

${ }^{87}$ FREUD, Sigmund. Ob. cit., p. 75.

${ }^{88}$ FREUD, Sigmund. Ob. cit., p. 67.

${ }^{89}$ FREUD, Sigmund. Ob. cit., p. 68.

${ }^{90}$ WITTGENSTEIN, Ludwig. Tratado lógico filosófico - Investigações filosóficas. $3^{\mathrm{a}}$ ed. Tradução M. S. Lourenço. Lisboa: Fundação Calouste Gulbenkian, 2002, p.283-298. Note-se que não 
se desconhece aqui as duas fases principais pelas quais passaram o pensamento do referido filósofo lingüista. Com efeito, utiliza-se nessa passagem específica sua primeira fase, não convencionalista, ao invés de sua segunda preponderantemente convencionalista. ${ }^{91}$ LACAN, Jacques. Televisão. Tradução: Antonio Quinet. Rio de Janeiro: Jorge Zahar Editor, 1993, p. 42.

${ }^{92}$ FREUD, Sigmund. Ob. cit., p. 69.

${ }^{93}$ BAUMAN. Zygmunt. O mal-estar da pós-modernidade. Tradução: Mauro Gama, Claudia Martinelli Gama. Rio de Janeiro: Jorge Zahar Editor, 1998, p.25-36.

${ }^{94}$ FREUD, Sigmund. Ob. cit., p. 70.

${ }^{95}$ FREUD, Sigmund. Ob. cit., p. 70.

${ }^{96}$ Convém salientar, por oportuno, com espeque na lição de Jean Baudrillard, que a Sociedade de Consumo, em certa medida, vale-se da mesma estratégia, ou seja, destrói o natural e por meio do signo reconstrói este de forma potencializada, produzindo a sensação ao final de que o artificial é mais real do que o real e que o real é uma ilusão equivocada. Nesse sentido, é que o sociólogo francês denuncia que a lógica que permeia o consumo é a da carência e a da diferenciação social. Consulte-se, BAUDRILLARD, Jean. A sociedade de consumo. Lisboa: 70 Arte \& Comunicação, 2007.

${ }^{97}$ Nesse passo, convém destacar a acepção de Ponty acerca do cogito, o qual assinala que "entre mim, que analiso a percepção, e o eu que percebe, há sempre uma distância. Mas, no ato concreto de reflexão, eu transponho essa distância, provo pelo fato que sou capaz de saber aquilo que eu percebia, domino praticamente a descontinuidade dos dois Eus, e finalmente o cogito terá por sentido não revelar um constituinte universal ou reconduzir a percepção à intelecção, mas constatar este fato da reflexão, que ao mesmo tempo domina e mantém a opacidade da percepção", vide: MERLEAU-PONTY, Maurice. Fenomenologia da percepção. Tradução: Carlos Alberto Ribeiro de Moura. $3^{a}$ ed. São Paulo: Martins Fontes, 2006, p. 74.

${ }^{98}$ A segurança é em si um mito, tanto porque, no que toca à sua abordagem fenomenológica, esta é fundamentalmente uma sensação, quanto porque, no que toca ao seu aspecto simbólico, essa tem a pretensão (se tem capacidade de proporcionar o fím a que se propõe, isso é bastante duvidoso) utilitária de proporcionar determinados fins, quais sejam, econômicos (principalmente), políticos e psicológicos, dentre outros, todos eles eivados de conteúdo ideológico. Enquanto mito que é, a segurança não é um dado, nem admite demonstração, é um objeto de fé para uns, e de manipulação e venda para outros. ${ }^{99}$ FREUD, Sigmund. Ob. cit., p. 71.

${ }^{100}$ BIRMAN, Joel. Mal-estar na atualidade: a psicanálise e as novas formas de subjetivação. $2^{\mathrm{a}}$ ed. Rio de Janeiro: Civilização Brasileira, 2000.

101 MAFFESOLI, Michel. Notas sobre a pos-modernidade - o lugar faz o elo. São Paulo: Atlântica Editora, 2004, p. 47.

102 MORIN, Edgar. Breve historia de la barbárie em ocidente. Buenos Aires: Paidos, 2007, p. 3346.

${ }^{103}$ FERRAZ JR. Tércio Sampaio. Introdução ao estudo do direito: técnica, decisão e dominação. São Paulo: Atlas, 2007, p. 308.

${ }^{104}$ FREUD, Sigmund. Totem e tabu. Volume XIII. Tradução: Órizon Carneiro Muniz. $2^{\mathrm{a}}$ edição. Rio de Janeiro: Imago Editora, 1995, p. 69.

105 ARISTÓTELES. Ética a nicômaco. São Paulo: Martin Claret, 2001, p. 23-27.

106 CHAUÍ, Marilena. Conformismo e resistência - aspectos da cultura popular do Brasil. São Paulo: Editora Brasiliense, 1986, p. 43-57.

107 A escolha é o ápice da sensação de mal-estar.

${ }^{108}$ DERRIDA, Jacques. Gramatologia. São Paulo: Perspectiva, 1973.

${ }^{109}$ FREUD, Sigmund. Totem e tabu. Volume XIII. Tradução: Órizon Carneiro Muniz. $2^{\mathrm{a}}$ ed. Rio de Janeiro: Imago Editora, 1995, p. 53-67. 
${ }^{110}$ Contudo, o homem pós-moderno não se apercebe de que a mesma informação que lhe traz um momento de segurança, será aquela que lhe propiciará, num instante seguinte, um estado de insegurança. Consome-se informação não porque o mundo globalizado esteja orientado por valores altruístas educacionais. Consome-se porque é preciso consumir, porque o consumo é a razão, é o próprio Ser (Deisen) do mundo pós-moderno. À medida que se consome o homem é levado a consumir mais. Todavia, à medida que se consomem novas informações outras são massificadas, e estas novas informações aumentam a probabilidade de refutação do conhecimento, das "ciências", das "verdades" físicas, da segurança, o que provoca no homem uma crise de abstinência informativa e o leva a novamente consumir.

${ }^{111}$ BAUDRILLARD, Jean. A sociedade de consumo. Lisboa: 70 Arte \& Comunicação, 2007, p. 7983.

112 BAUMAN. Zygmunt. O mal-estar da pós-modernidade. Tradução: Mauro Gama, Claudia Martinelli Gama. Rio de Janeiro: Jorge Zahar Editor, 1998, p. 7.

${ }^{113}$ BAUMAN, Ob. cit., p. 7.

${ }^{114}$ MORIN, Edgar. Cultura e barbárie européias. Lisboa: Instituto Piaget, 2007.

${ }^{115}$ MORIN, Ob. cit., p. 8.

116 ARISTÓTELES. Ética a nicômaco. São Paulo: Martin Claret, 2001, p. 23.

117 ARISTÓTELES, Ob. cit., p. 26.

118 O "Grande Irmão" (em inglês: Big Brother) é um personagem fictício no romance "1984" de George Orwell, o enigmático ditador da Oceania. Na sociedade descrita por Orwell, todos as pessoas estão sob constante vigilância das autoridades, principalmente por teletelas (telescreen), sendo constantemente lembrados pela frase propaganda do Estado: "o Grande Irmão zela por ti” ou "o Grande Irmão está te observando" (do original "Big Brother is watching you"). A descrição física do "Grande Irmão" assemelha-se a Josef Stalin ou Horatio Herbert Kitchener. O conceito originado transposto para a sociedade moderna é o domínio das massas por mídias, se não totalitárias, mas na condição de quase monopólio de audiência. Elas podem ditar regras nos costumes, fazer e/ou desfazer idolatrias e fazerem- -se de vias para a condução de uma cultura.

119 BAUMAN. Zygmunt. O mal-estar da pós-modernidade. Tradução: Mauro Gama, Claudia Martinelli Gama. Rio de Janeiro: Jorge Zahar Editor, 1998, p. 8.

${ }^{120}$ BAUMAN, Ob. cit. p. 8.

121 ALEXY, Robert. Teoria de los derechos fundamentales. Madrid: Centro de Estudos Políticos e Constitucionales, 2002. p. 86.

${ }^{122}$ DWORKIN, Ronald. Levando os direitos a sério. Trad. Jéferson Luiz Camargo. 2a ed. São Paulo: Martins Fontes, 2007, p. 32-43.

${ }^{123}$ ALEXY, Robert. Teoria dos direitos fundamentais. Tradução: Virgilio Afonso da Silva. São Paulo: Malheiros, 2008, p. 92.

${ }^{124}$ FREUD, Sigmund. O futuro de uma ilusão/O mal-estar na civilização. Volume XXI. Tradução: Órizon Carneiro Muniz. 2a ed. Rio de Janeiro: Imago Editora, 1999, p. 27.

${ }^{125}$ FREUD, Ob. cit., p. 25.

${ }^{126}$ ALEXY, Robert. Teoria de los derechos fundamentales. Madrid: Centro de Estudos Políticos e Constitucionales, 2002. p. 97-101.

${ }^{127}$ PERELMAN, Chaïm; TYTECA, L. Olbrechts. Tratado da argumentação. a nova retórica. Tradução: Maria Ermantina de Almeida Prado Galvão. São Paulo: Martins Fontes, 2005.

${ }^{128}$ FERRAZ JR. Tércio Sampaio. Introdução ao estudo do direito: técnica, decisão e dominação. São Paulo: Atlas, 2007, p. 312.

${ }^{129}$ CÍCERO, Marco Túlio. Retórica a herênio. Tradução: Adriana Seabra e Ana Paula Celestino Faria. São Paulo: Hedra, 2005, passim.

${ }^{130}$ FERRAZ JR. Tércio Sampaio. Introdução ao estudo do direito: técnica, decisão e dominação. São Paulo: Atlas, 2007, p. 294. 
131 VIEHWEG, Theodor. Tópica e jurispudência. Uma contribuição à investigação dos fundamentos jurídico-científicos. Tradução: Kelly Alfen da Silva. Porto Alegre: Safe, 2008.

${ }^{132}$ HÄBERLE, Peter. Hermenêutica constitucional. Tradução Gilmar Ferreira Mendes. Porto Alegre: Sergio Antonio Fabris Editor, 1997, p. 15-16.

${ }^{133}$ CANOTILHO, J. J. Gomes. Direito constitucional e teoria da constituição. $4^{\mathrm{a}}$ ed. Coinbra: Almedina, 2000, p. 235-240.

134 Ressalte-se, nesse passo, a lógica do consumo que permeia os meios de comunicação de massa, notadamente com a produção de "manchetes bombásticas" e a comercialização da violência como produto de consumo. Aliás, convém pôr em relevo, com espeque na lição de Jean Baudrillard, que a violência na sociedade do consumo desempenha as seguintes funções e apresenta os seguintes aspectos: a) a grande massa "pacificada" é quotidianamente alimentada pela violência consumida e pela violência alusiva à toda substância apocalíptica do "mass media", como forma de dar vazão à agressividade e ao instinto destrutivo inerente ao ser humano (além do fascínio - poder e prazer - exercido pela morte); b) a violência como estratégia para despertar uma obsessão por segurança e bem-estar e provocar uma febre de consumo bélico; c) a violência "espetacularizada" e o conformismo da vida quotidiana como realidades abstratas que se alimentam de mitos e signos; d) a violência ministrada em “doses homeopáticas" pela mídia como forma de realçar a fragilidade real da vida pacificada, vez que é o espectro da fragilidade que assedia a civilização da abundância, à medida que evidencia o equilíbrio precário que firma a ordem de contradições que constitui a sociedade contemporânea; e) a violência inexplicada como uma imposição de revisão das ideias de abundância e das taxas de crescimento da economia, face às contradições fundamentais da abundância; $\mathrm{f}$ ) a violência que desperta como consequências, dentre outras, a destrutividade das instituições e a depressividade contagiosa da população, passando por condutas coletivas de fuga (como, por exemplo, o aumento do consumo de drogas ilícitas ou não); g) a violência que resulta da pulsão desencadeada pelo consumo, o condicionamento do espectador diante do apelo do espetáculo, como estratégia de manipulação do desejo; h) a violência que conduz a reabsorção das angústias através da proliferação das terapias, dos tranquilizantes, ou seja, a sociedade de abundância, produtora de satisfação sem finalidade, esgota os recursos a produzir o antídoto para a angústia derivada da satisfação. Consulte-se, BAUDRILLARD, Jean. A sociedade de consumo. Lisboa: 70 Arte \& Comunicação, 2007, p. 184-191.

${ }^{135}$ MARCONDES FILHO, Ob. cit., p. 18.

136 A televisão torna a memória descartável. O passado é embolorado, o futuro demanda o tempo, por isso, é custoso. Logo, a televisão é o altar no qual se celebra o tempo presente, o imediato. Mas não apenas isto. A televisão desperta no homem a preguiça de pensar, pois ela pensa por ele. A televisão não é espaço democrático de participação, pelo contrário, é veículo sufragado numa linguagem autoRrefencial. Desta forma, a televisão não fala o homem, ela fala de si, não é a arte que imita a vida, é a vida que é manipulada pela arte. Por isso, o homem pós-moderno, além de não possuir identidade, sofre de amnésia crônica. Por conseguinte, a memória, que é a evidência da historicidade e da existência, é resíduo radioativo que deve se ter bem à distância do cidadão. Por outro lado, a memória viabiliza a construção do conceito de tempo, potencializa a recordação de uma impressão do passado e a imaginação de um futuro, ou, como prefere Jacques Lacan, a memória é uma combinação linguística. Por conseguinte, é possível asseverar, assim, que o tempo é uma convenção de linguagem, dentro da qual o homem pós-moderno se enclausurou. LACAN, Jacques. Televisão. Tradução: Antonio Quinet. Rio de Janeiro: Jorge Zahar Editor, 1993, p. 42-63.

137 POPPER, Karl; CONDRY, John. Televisão: um perigo para a democracia. Tradução: Maria Carvalho. $3^{\text {a }}$ ed. Lisboa: Gradiva, 2007. 
${ }^{138}$ MARCONDES FILHO, Ciro. Televisão. São Paulo: Editora Scipione, 1994, p. 36.

139 "O mais absurdo é que nunca são mostradas pessoas a trabalhar nem o modo como adquiriram os bens que exibem. Não se estabelece qualquer relação entre riqueza e trabalho. As crianças, que preferem as soluções mais fáceis, aspiram à felicidade tal como é definida na televisão, ou seja, possuir bens materiais, mas não sabem o que precisam fazer para os obterem". POPPER, Karl; CONDRY, John. Ob. cit., p. 49.

${ }^{140}$ Karl Popper compreende que a televisão representa um perigo para a democracia, também porque esta amolda a criança de hoje e o cidadão de amanhã a uma lógica nefasta e violenta. "As crianças de hoje são cruéis umas com as outras, e são desprovidas de compaixão, se troçam dos fracos e desprezam quem precisa de ajuda, será que isso se deve ao que vêem na televisão?". POPPER, Karl; CONDRY, John. Ob. cit., p. 15 e 48.

${ }^{141} \mathrm{O}$ sensacionalismo midiático em torno da criminalidade é o fruto mais amargo da cumplicidade entre um aparelho policial ineficiente e uma imprensa que ouve e publica. É rotina: crimes complexos, intrincados, embalados por paixões e mistérios, são desvendados instantaneamente para jornalistas, aos quais não ocorre perguntar: "Como o senhor descobriu tudo isso em tão pouco tempo?" Se o jornalista pergunta, perde a notícia. Ademais, não é verdade que os jornais só publicam informações de fontes oficiais, quase sempre a vítima é a fonte mais segura e inquestionável das informações divulgadas. MARCONDES FILHO, Ob. cit., p. 3-4.

${ }^{142}$ BOURDIEU, Pierre. Acerca de la television. Tradução: Roberto Marafiotti. Disponível em: http://metrallapoetika2.googlepages.com/BourdieuPierre-Acercadelatelevisiond.doc. Acesso em: 15/06/08.

${ }^{143}$ POPPER; CONDRY, Ob. cit., p. 7.

${ }^{144}$ POPPER; CONDRY, Ob. cit., p. 8.

${ }^{145}$ POPPER; CONDRY, Ob. cit., p. 9.

${ }^{146}$ POPPER; CONDRY, Ob. cit., p. 9.

${ }^{147}$ POPPER, Karl. A sociedade aberta e seus inimigos. Volume I. $3^{\text {a }}$ ed. Rio de Janeiro: Editora Itatiaia, 1998, passim.

${ }^{148}$ POPPER; CONDRY, Ob. cit., p. 10.

${ }^{149}$ POPPER; CONDRY, Ob. cit., p. 10.

${ }^{150}$ POPPER; CONDRY, Ob. cit., p. 10.

${ }^{151}$ POPPER; CONDRY, Ob. cit., p. 10.

${ }^{152}$ BOURDIEU, Ob. cit., p. 16.

${ }^{153}$ LIMA BARRETO, Afonso Henriques de. Triste fim de Policarpo Quaresma. Disponível: http://www.cce.ufsc.br/ nupill/literatura/quaresma.html. Acesso em: 02/01/07.

${ }^{154}$ POPPER; CONDRY, Ob. cit., p. 11.

155 A televisão reconstitui o mundo de uma forma especial. A telenovela torna-se o mundo real e o telejornal o mundo ficcional. A novela é tão cotidiana quanto a própria vida. Tornou-se um componente necessário da existência, uma espécie de preenchimento da necessidade de vivência. O mundo do homem é na medida de seus anseios e angústias. MARCONDES FILHO, Ob. cit., p. 38-41.

${ }^{156}$ Reflexão que apresentaria o seguinte conjunto de medidas: a censura aos programas violentos, a imposição de um compromisso legal aos que trabalham com a televisão, a instituição de uma autorização revogável. $O$ que se visa não é a censura da televisão, mas uma televisão com compromisso moral. POPPER; CONDRY, Ob. cit., p. 12.

${ }^{157}$ POPPER; CONDRY, Ob. cit., p.13.

${ }^{158}$ BOURDIEU, Ob. cit., p. 4-5.

${ }^{159}$ BOURDIEU, Ob. cit., p. 19-22.

${ }^{160}$ BAUDRILLARD, Jean. A sociedade de consumo. Lisboa: 70 Arte \& Comunicação, 2007, p. 184-191.

${ }^{161}$ LACAN, Ob. cit., p.49-60. 
162 "Entre os valores finais havia um que dominava todos os outros: 'a felicidade'. Este valor surgia em quase $60 \%$ das seqüências publicitárias, ou seja, duas vezes mais, pelo menos, do que qualquer outro. 'O reconhecimento pessoal' vinha em segundo lugar. Os valores finais que preconizavam o egoísmo ou o egocentrismo (tais como a felicidade pessoal, uma vida interessante, o reconhecimento social) eram citados muito mais vezes do que valores altruístas com a igualdade e a amizade". POPPER; CONDRY, Ob. cit., p. 56. ${ }^{163}$ A condição do inconsciente é a linguagem, por isso o pensamento só tem com o almacorpo uma relação de ex-sistência e muito pouco do que se chama de real provém do que se entende por real. Mas não apenas isto. Só existe estrutura de linguagem à medida que a língua é a condição do sentido. Nestes termos, basta um significante para fundar o significante "Um". Não se iluda, bicho-homem, não há harmonia entre o Ser e o mundo. LACAN, Ob. cit., p. 17-25.

${ }^{164}$ MARCONDES FILHO, Ob. cit., p. 84.

165 “(...) as pessoas não vêem mais necessidade de uma troca real, física com aqueles que estão ao seu redor, que com elas convivem, mas satisfazem-se apenas com a substituição a partir desse aparelho eletrônico. A televisão funcionando como a máquina narcísica, através da qual, não existindo mais a comunidade, a família, os amigos, vira apenas uma maneira de cada um embebedar-se, organizando sua programação, compondo sua satisfação por si e exclusivamente para si, num universo autista". MARCONDES FILHO, Ob. cit., p. 84.

166 "Separação cada vez mais marcante entre si mesmo e o mundo com a rejeição subseqüente da consciência do mundo exterior, um auto-recolhimento estimulado e anulação das diferenças temporais em função de um presente permanente". MARCONDES FILHO, Ob. cit., p. 85.

${ }^{167}$ MARCONDES FILHO, Ob. cit., p. 58-59.

${ }^{168}$ Comunicação instantânea por meio de ideias recebidas não é comunicação, pois o receptor da mensagem não pensa sobre essa, mas a repete.

${ }^{169}$ MARCONDES FILHO, Ob. cit., p. 81-83.

${ }^{170}$ FOUCAULT, Michel. Microfísica do poder. Rio de Janeiro: Graal, 1979, p. 67-81.

${ }^{171}$ POPPER; CONDRY, Ob. cit., p. 78-79.

172 ZAFFARONI, Eugênio Raul. Em busca das penas perdidas. A perda de legitimidade do sistema penal. Tradução: Vânia Romano Pedrosa e Amir Lopez da Conceição. Rio de Janeiro: Revan, 1991, p. 45-70.

${ }^{173}$ CARVALHO, Salo de. Antimanual de criminologia. Rio de Janeiro: ITEC \& Lumen Juris, 2008, p. 57-78.

${ }^{174}$ FIGUEIREDO DIAS, Jorge; ANDRADE, Manuel da Costa. Criminologia. Coimbra: Coimbra Ed., 2006. passim.

${ }^{175}$ MARCONDES FILHO, Ob. cit., p. 74-76.

${ }^{176}$ STF, SÚMULA VINCULANTE n 11: "Só é lícito o uso de algemas em casos de resistência e de fundado receio de fuga ou de perigo à integridade física própria ou alheia, por parte do preso ou de terceiros, justificada a excepcionalidade por escrito, sob pena de responsabilidade disciplinar, civil e penal do agente ou da autoridade e de nulidade da prisão ou do ato processual a que se refere, sem prejuízo da responsabilidade civil do Estado".

177 POPPER; CONDRY, Ob. cit., p. 72.

$178 \mathrm{O}$ telejornal não tem razão "para ter qualquer conta com a realidade. Se a deformação da realidade permite captar a atenção dos telespectadores, não há que hesitar". POPPER; CONDRY, Ob. cit., p. 46.

${ }^{179}$ LACAN,.Ob. cit., p. 29-30.

180 “(...) no decurso de dois dias de programação televisiva referenciamos 149 mensagens relacionadas com drogas. Nesse total havia 121 mensagens favoráveis $(81,2 \%)$ e 22 
desfavoráveis $(14,8 \%)$, sendo 6 ambíguas. Em suma, para cada mensagem desfavorável havia seis mensagens favoráveis e, para certas drogas, a proporção era ainda mais forte: no que toca ao álcool, por exemplo, havia dez mensagens favoráveis por cada mensagem desfavorável". POPPER; CONDRY, Ob. cit., p. 51. Ou seja, para cada mensagem que diz "recuse as drogas", seis afirmam "se não se sente bem, tome qualquer coisa, que melhora". POPPER; CONDRY, Ob. cit., p. 52.

${ }^{181}$ MARCONDES FILHO, Ob. cit., p. 84.

${ }^{182}$ MARCONDES FILHO, Ob. cit., p. 84.

${ }^{183}$ MARCONDES FILHO, Ob. cit., p. 85.

${ }^{184}$ BOURDIEU, Ob. cit., p. 15-17.

185 ANDRADE, Jose Helder de Souza. Segurança X sensação de segurança. São Paulo: Ciência Moderna, 2002, p. 45-57.

${ }^{186}$ BOURDIEU, Ob. cit., p. 14.

${ }^{187}$ LACAN, Ob. cit., p. $74-86$.

${ }^{188}$ BOURDIEU, Ob. cit., p.3.

${ }^{189}$ COUTINHO, Carlos Nelson. Gramsci: um estudo sobre seu pensamento politico. Rio de Janeiro: Civilização Brasileira, 1999.

${ }^{190}$ LACAN, Jacques. Ob. cit. p.77-82.

${ }^{191}$ RODRIGUES DE SOUZA, Rafael Bellan. Gramsci e a comunicação: a mídia como aparelho privado de hegemonia. Disponível em: «http://www.faac.unesp.br/eventos/jornada2005/ trabalhos/26_rafael_bellan.htm.» Acesso em: 03 jul. 2008.

${ }^{192}$ LIMA, Venício A. de. Mídia: teoria e política. São Paulo: Fundação Perseu Abramo, 2001, p. 190-191.

193 "A mídia substitui algumas das tradicionais funções do partido, tais como: definir a agenda dos temas relevantes para a discussão na esfera pública, gerar e transmitir informações políticas, fiscalizar a ação das administrações públicas e canalizar as demandas da população junto ao governo. Ao aparecer como o principal (mas de forma alguma único) aparelho privado de hegemonia, os meios de comunicação aparecem como um espaço de luta política fundamental na construção contra-hegemônica". RODRIGUES DE SOUZA, Rafael Bellan. Gramsci e a comunicação: a mídia como aparelho privado de hegemonia. Disponível em: «http://www.faac.unesp.br/eventos/jornada2005/trabalhos/ 26_rafael_bellan.htm. Acesso em: 03/07/2008». Acesso em: 03 jul.2008.

${ }^{194}$ BOURDIEU, Ob. cit., p. 4.

${ }^{195}$ NEVES, Marcelo. A constitucionalização simbólica. São Paulo: WMF Martins Fontes, 2007, p. $42-50$.

${ }^{196}$ DI GIORGI, Alessandro. A miséria governada através do sistema penal. Rio de Janeiro: Revan, ICC, 2006, p. 94-102.

${ }^{197}$ Apud MARCONDES FILHO, Ob. cit., p.23.

${ }^{198}$ WEBER, Max. Economia e sociedade. Volume I. Brasília: Unb, 2004, p. 56- 161.

${ }^{199}$ PAI E TIA de Isabela Nardoni depõem à Justiça nesta quarta. Matéria publicada em 03/ 07/2008 às 09h49m. O globo online. Disponível em: «http://oglobo.globo.com/sp/mat/ 2008/07/03/pai_tia_de_isabella_nardoni_depoem_justica_nesta_quarta-547079419.asp». Acesso em: 07 jul. 2008.

${ }^{200}$ SUZANE VON RICHTHOFEN quer anular julgamento que a condenou a 39 anos de prisão. Matéria publicada em 16/01/2008 às $11 \mathrm{~h} 52 \mathrm{~m}$. O globo online. Disponível em: «http:/ / o g lob o.globo.com/s p/mat/2008/01/ $16 /$ suzane_von_richthofen_quer_anular_julgamento_que_condenou_39_anos_de_prisao328044733.asp». Acesso em: 07 jul. 2008.

${ }^{201}$ MENOR ENVOLVIDO em morte de menino ficará preso por no máximo três anos. Matéria publicada em $08 / 02 / 2007$ às $23 \mathrm{~h} 33 \mathrm{~m}$. O globo online. Disponível em: «http:// oglobo.globo.com/rio/mat/2007/02/08/294494115.asp». Acesso em: 07 jul. 2008. 
202 GRAMSCI, Antonio. Os intelectuais e a organização da cultura. Rio de Janeiro: Civilização Brasileira, 1995.

203 Apud MARCONDES FILHO, Ob. cit., p. 32.

204 Apud MARCONDES FILHO, Ob. cit., p. 35.

205 Apud MARCONDES FILHO, Ob. cit., p. 25.

206 Apud MARCONDES FILHO, Ob. cit., p. 25.

${ }^{207}$ MARCONDES FILHO, Ob. cit., p. 39.

${ }^{208}$ MÉSZÁROS, István. O poder da ideologia. São Paulo: Boitempo, 2004.

${ }^{209}$ Expressão ambígua que veicula o arbítrio estatal sob o manto de uma suposta discricionariedade. Discricionaridade sempre pressupõe legalidade. Expressão vazia destituída de caráter cautelar e serviente a uma ideologia de antecipação da pena, submissa a uma compreensão preventiva da prisão provisória.

${ }^{210}$ BAUMAN. Zygmunt. O mal-estar da pós-modernidade. Tradução: Mauro Gama, Claudia Martinelli Gama. Rio de Janeiro: Jorge Zahar Editor, 1998, passim.

${ }^{211}$ SILVA NETO, Manoel Jorge e. Direito constitucional econômico. $1^{\text {a }}$ ed. São Paulo: LTr, 2001, p. 18.

${ }^{212}$ WARAT, Luís Alberto. Mitos e teorias na interpretação da lei. Porto Alegre: Síntese, 1979, passim

${ }^{213}$ Perfil das vítimas e agressores das ocorrências registradas pelas polícias civis

(Janeiro de 2004 a Dezembro de 2005). Disponível em:«http://www.mj.gov.br/data/ Pages/MJCF2BAE97ITEMID78EA9AA6C582483FA694D19FA0A90410PTBRIE.htm». Acesso em: 03 jul.2008.

214 SENSAÇÃO DE INSEGURANÇA no Brasil é a maior do mundo, diz ONU. Matéria publicada em 01/10/2007 às 17h15m. O globo online Reuters. Disponivel em: " http:// oglobo.globo.com/pais/mat/2007/10/01/297954994.asp». Acesso em: 03 mar. 2008.

\section{REFERÊNCIAS}

ADEODATO, João Maurício. Filosofia do direito - Uma crítica à verdade na ética e na ciência. $3^{a}$ ed. São Paulo: Saraiva, 2007.

ALEXY, Robert. Teoria dos direitos fundamentais. Tradução: Virgilio Afonso da Silva. São Paulo: Malheiros, 2008.

. Teoria de los derechos fundamentales. Madrid: Centro de Estudos Políticos e Constitucionales, 2002.

ANDRADE, José Helder de Souza. Segurança X Sensação de segurança. São Paulo: Ciência Moderna, 2002.

ANIYAR DE CASTRO, Lola. Criminologia da reação social. Trad. E. Kosowski, Rio de Janeiro: Forense, 1983.

ARISTÓTELES. Ética a Nicômaco. São Paulo: Martin Claret, 2001.

ÁVILA, Humberto. Teoria dos princípios - da definição à aplicação dos princípios jurídicos. São Paulo: Malheiros, 2003.

AZEVÊDO, Bernardo Montalvão Varjão de. A importância dos atos de comunicação para o processo penal: o esboço de uma teoria geral e uma análise descritiva. Rio de Janeiro: Lumen Juris, 2008. 
- Uma reflexão acerca dos pactos e convenções internacionais e sua aplicação no ordenamento jurídico pátrio. In Revista de Direito Constitucional e Internacional, v. 43. São Paulo: RT, 2003.

. O Amor como fundamento legitimador do Direito. Revista forense. v. 383. Rio de Janeiro: Forense, 2006.

BARATTA, Alessandro. Criminologia crítica e crítica do direito penal Introdução à sociologia do direito penal. Trad. Juarez Cirino dos Santos, Rio de Janeiro: Freitas Bastos Editora, 1999.

BARRETO, Tobias. Introdução do estudo do direito - politica brasileira. São Paulo: Landy Editora, 2001.

BARROSO, Luís Roberto. Interpretação e aplicação da constituição. $3^{\mathrm{a}} \mathrm{ed}$. São Paulo: Saraiva, 1999.

BASTOS, Celso Ribeiro. O abuso do poder econômico e o projeto de lei $n^{\circ}$ 3.712. São Paulo: Max Limonad. Revista do Programa de PósGraduação em Direito da PUC/SP, 1995.

BAUDRILLARD, Jean. A sociedade de consumo. Lisboa: 70 Arte \& Comunicação, 2007.

Simulacros e simulação. Tradução: Maria João Pereira. Lisboa: Relógio D’água, 1997.

BAUMAN. Zygmunt. Identidade. Tradução: Plínio Dentzien. Rio de Janeiro: Jorge Zahar Editor, 2005.

. Modernidade líquida. Tradução: Plínio Dentzien. Rio de Janeiro: Jorge Zahar Editor, 1999.

- O mal-estar da pós-modernidade. Tradução: Mauro Gama, Claudia Martinelli Gama. Rio de Janeiro: Jorge Zahar Editor, 1998.

BAZDRESCH, Luiz. Curso elementar de garantias constitucionales. México: Editorial Jus, 1977.

BENJAMIN, Walter. Para uma crítica de la violencia. Disponível em: http:/ / http://www.ddooss.org/articulos/textos/walter_benjamin.pdf. Acesso em: 20.05.2008.

BIRMAN, Joel. Mal-estar na atualidade: a psicanálise e as novas formas de subjetivação. $2^{a}$ edição. Rio de Janeiro: Civilização Brasileira, 2000.

BOBBIO, Noberto. Teoria do ordenamento jurídico. Tradução: Maria Celeste C. J. Santos10ª edição. Brasilia: Editora Unb, 1999.

BONAVIDES, Paulo. Curso de direito constitucional. $10^{a}$ ed. São Paulo: Malheiros, 2000.

BOURDIEU, Pierre. La distincion - Criterio y bases sociales del gusto. Madrid: Taurus, 2000. 
- Acerca de la Television. Tradução: Roberto Marafiotti. Disponível em: http://metrallapoetika2.googlepages.com/BourdieuPierreAcercadelatelevisiond.doc. Acesso em: 15/06/08.

CANARIS, Claus-Wilhelm. Pensamento sistemático e conceito de sistema na ciência do direito. $3^{\mathrm{a}}$ ed. Lisboa: Fundação Calouste Gulbenkian, 2002. CANOTILHO, José Joaquim Gomes. Direito constitucional e teoria da constituição. $3^{a}$ ed. Coimbra: Almedina, 1999.

; MOREIRA, Vital. Constituição da República Portuguesa anotada. V. 1. $1^{a}$ edição brasileira. São Paulo: RT e Coimbra Editora, 2007.

CARRIÓ, Genaro. Notas sobre derecho y lenguaje. $4^{a}$ ed. Buenos Aires: Abeledo-Perrot, 1990.

CARVALHO, Salo de. Antimanual de criminologia. Rio de Janeiro: ITEC \& Lumen Juris, 2008.

CASTORIADIS, Cornelius. A instituição imaginária da sociedade. Florianópolis: Paz e Terra, 2007.

COUTINHO, Carlos Nelson. Gramsci: um estudo sobre seu pensamento político. Rio de Janeiro: Civilização Brasileira, 1999.

CÍCERO, Marco Túlio. Retórica a berênio. Tradução: Adriana Seabra e Ana Paula Celestino Faria. São Paulo: Hedra, 2005.

CHAUÍ, Marilena. Conformismo e resistência - aspectos da cultura popular do Brasil. São Paulo: Editora Brasiliense, 1986.

DERRIDA, Jacques. Gramatologia. São Paulo: Perspectiva, 1973.

DIAS, Jorge Figueiredo. Direito penal. Parte geral. Tomo I. Coimbra: Coimbra Editora, 2004.

; Andrade, Manuel da Costa. Criminologia. Coimbra: Coimbra Ed., 2006.

DI GIORGI, Alessandro. A miséria governada através do sistema penal. Rio de Janeiro: Revan, ICC, 2006.

DWORKIN, Ronald. Levando os direitos a sério. Trad. Jéferson Luiz Camargo. 2. ed. São Paulo: Martins Fontes, 2007.

ECO, Umberto. Interpretação e superintepretação. São Paulo: Martins Fontes, 2005.

FARIA, José Eduardo (Org.). Direito e globalização econômica: implicações e perspectivas. São Paulo: Malheiros, 1996.

FERRAJOLI, Luigi. A soberania no mundo moderno - nascimento e crise do estado nacional. Tradução Carlo Coccioli e Márcio Lauria Filho; revisão da Tradução Karina Jannini. São Paulo: Martins Fontes, 2002. 
FERRAZ JR. Tércio Sampaio. Introdução ao estudo do direito: técnica, decisão e dominação. São Paulo: Atlas, 2007.

FOUCAULT, Michel. Microfísica do poder. Rio de Janeiro: Graal, 1979.

. Os anormais. São Paulo: Martins Fontes, 2002.

. Vigiar e punir. Petrópolis: Vozes, 2003.

FREUD, Sigmund. Totem e tabu. Volume XIII. Tradução: Órizon Carneiro Muniz. $2^{a}$ edição. Rio de Janeiro: Imago Editora, 1995.

. O Futuro de uma ilusão/O mal-estar na civilização. Volume XXI.

Tradução: Órizon Carneiro Muniz. $2^{\mathrm{a} e d i c ̧ a ̃ o . ~ R i o ~ d e ~ J a n e i r o: ~ I m a g o ~}$ Editora, 1999.

GADAMER, Hans-Georg. Verdade e método I: traços fundamentais de uma bermenêutica filosófica. Tradução: Flávio Paulo Meurer. 7. ed. Petrópolis: Vozes - Universidade São Francisco, 2005.

GRAMSCI, Antonio. Os intelectuais e a organização da cultura. Rio de Janeiro: Civilização Brasileira, 1995.

GRAU, Eros Roberto. A ordem econômica na Constituição de 1988. $6^{a}$ edição. São Paulo: Malheiros, 2001. . Ensaio e discurso sobre a interpretação/Aplicação do direito. $3^{\mathrm{a}} \mathrm{ed}$. São Paulo: Malheiros, 2005.

HÄBERLE, Peter. Hermenêtica constitucional. A sociedade aberta dos intérpretes. Tradução Gilmar Ferreira Mendes. Porto Alegre: Sergio Antonio Fabris Editor, 1997.

HABERMAS, Jürgen. A inclusão do outro - estudos de teoria política. $2^{\mathrm{a}} \mathrm{ed}$. Tradução: George Sperber, Paulo Astor Soethe e Milton Camargo Mota. São Paulo: Loyola, 2004.

. Direito e democracia entre facticidade e validade. Volume I, $2^{\mathrm{a}}$ Ed., Tradução: Flávio Beno Siebeneichler. Rio de Janeiro: Tempo Brasileiro, 2003.

HESPANHA, António Manuel. O direito e a justica nos dias e no mundo de hoje. Coimbra: Almedina, 2007.

HESSE, Konrad. Elementos de direito constitucional da República Federal da Alemanha. Tradução Luís Afonso Heck. Porto Alegre: Sergio Antpnio Fabris, 1998.

KÜHN, Thomas. A estrutura das revoluçoes científicas. $3^{a}$ edição. São Paulo: Perspectiva, 1991.

LACAN, Jacques. Televisão. Tradução: Antonio Quinet. Rio de Janeiro: Jorge Zahar Editor, 1993. 
LARENZ, Karl. Metodologia da ciência do direito. $3^{a}$ ed. Tradução de José Lamêgo. Lisboa: Fundação Calouste Gulbenkian, 1997.

LASSALE, Ferdinand. A essência da constituição. $6^{a}$ edição. Rio de Janeiro: Lúmen Júris, 2001.

LEVY, Pierre. Cibercultura. São Paulo: Editora 34, 1999.

LIMA, Venício A. de. Mídia: teoria e política. São Paulo: Fundação Perseu Abramo, 2001.

LIMA BARRETO, Afonso Henriques de. Triste fim de Policarpo Quaresma. Disponível: http://www.cce.ufsc.br/ nupill/literatura/quaresma.html. Acesso em: 02/01/07.

LOPES JR., Aury Celso Lima. Direito processual penal e sua conformidade constitucional. Volume I. Rio de Janeiro: Lumen Juris, 2007.

Sistemas de investigação preliminar no processo penal. Rio de Janeiro: Lumen Juris, 2003.

LUHMANN, Niklas. Sociologia do direito I. Tradução: Gustavo Bayer. Rio de Janeiro: Edições Tempo Brasileiro, 1983.

Sociologia do direito II. Tradução: Gustavo Bayer. Rio de Janeiro: Edições Tempo Brasileiro, 1983.

LYOTARD, Jean-François. A condição-pós moderna. Tradução: Wilmar do Valle Barbosa. Rio de Janeiro: Editora José Olympio, 2006.

. Lo inbumano: charlas sobre el tiempo. Buenos Aires: Manantial, 1998.

MAFFESOLI, Michel. Notas sobre a pós-modernidade - O lugar faz o elo. São Paulo: Atlântica Editora, 2004.

MARCONDES FILHO, Ciro. Televisão. São Paulo: Editora Scipione, 1994.

MARCUSE, Herbert. Ideologia da sociedade industrial. Rio de Janeiro: Zahar Editores, $3^{a}$ edição, 1969.

MELLO, Celso Antônio Bandeira de. Curso de direito administrativo. 19a ed. São Paulo: Malheiros, 2005.

MENOR ENVOLVIDO em morte de menino ficará preso por no máximo três anos. Matéria publicada em 08/02/2007 às $23 \mathrm{~h} 33 \mathrm{~m}$. $O$ Globo Online Disponível em: «http://oglobo.globo.com/rio/mat/ 2007/02/08/294494115.asp». Acesso em: 07 jul.2008.

MERLEAU-PONTY, Maurice. Fenomenologia da percepção. Tradução: Carlos Alberto Ribeiro de Moura. 3. ed. São Paulo: Martins Fontes, 2006.

MÉSZÁROS, István. O poder da ideologia. São Paulo: Boitempo, 2004. 
MIRANDA, Jorge. Teoria do estado e da constituição. Coimbra: Coimbra Editora, 2005.

MORIN, Edgar. Breve historia de la barbárie em ocidente. Buenos Aires: Paidos, 2007.

. Cultura e barbárie européias. Lisboa: Instituto Piaget, 2007.

MORRISON, Wayne. Filosofia do direito - Dos gregos ao pós-modernismo. Tradução Jefferson Luiz Camargo. São Paulo: Martins Fontes, 2006.

MÜLLER, Friedrich. Métodos de trabalho do direito constitucional. Tradução: Peter Naumann. $2^{a}$ edição. São Paulo: Max Limonad, 2000.

NEVES, Marcelo. A constitucionalização simbólica. São Paulo: WMF Martins Fontes, 2007.

OLIVEIRA, Eugênio Pacelli de. Curso de processo penal. $8^{\mathrm{a}}$ ed. Rio de Janeiro: Lumen Juris, 2007.

PAI E TIA de Isabela Nardoni depõem à Justiça nesta quarta. Matéria publicada em 03/07/2008 às 09h49. O Globo Online. Disponível em: «http://oglobo.globo.com/sp/mat/2008/07/03/ pai_tia_de_isabella_nardoni_depoem_justica_nesta_quarta547079419.asp». Acesso em: 07 jul.2008.

PASUKANIS, Eugeni B. Teoría general del derecho y marxismo. Trad.: Virgílio Zapatero, Barcelona: Labor, 1976.

PERELMAN, Chaïm; TYTECA, L. Olbrechts. Tratado da argumentação. A nova retórica. Tradução: Maria Ermantina de Almeida Prado Galvão. São Paulo: Martins Fontes, 2005.

POPPER, Karl. A sociedade aberta e seus inimigos. Volume I. $3^{\text {a }}$ edição. Rio de Janeiro: Editora Itatiaia, 1998.

- Lógica das ciências sociais. Tradução: Estevão de Rezende Martins, Apio Cláudio Muniz, Vilma de Oliveira Moraes e Silva. $3^{a}$ ed. Rio de Janeiro: Tempo Brasileiro, 2004.

; CONDRY, John. Televisão: um perigo para a democracia. Tradução: Maria Carvalho. $3^{a}$ edição. Lisboa: Gradiva, 2007.

RODRIGUES DE SOUZA, Rafael Bellan. Gramsci e a comunicação: a midia como aparelho privado de hegemonia. Disponível em: «http:// www.faac.unesp.br/eventos / jornada 2005 / trabalhos / 26_rafael_bellan.htm. Acesso em: 03/07/2008». Acesso em: 03 jul.2008.

RORTY, Richard. Contingência, ironia e solidariedade. Tradução: Vera Ribeiro. São Paulo: Martins Fontes, 2007. 
SANTOS, Boaventura de Sousa. Introdução a uma ciência pós-moderna. $4^{a}$ edição. Rio de Janeiro: Graal, 1989.

Um discurso sobre as ciências. $4^{a}$ ed. São Paulo: Cortez, 2006.

SANTOS, Juarez Cirino dos. Direito penal - Parte geral. $2^{\mathrm{a}}$ ed. Rio de Janeiro: Lumen Juris, 2007.

SARTRE, Jean-Paul. Freud, além da alma. Tradução: Jorge Laclette. Rio de Janeiro: Editora Nova Fronteira, 1986.

SENSAÇÃO DE INSEGURANÇA no Brasil é a maior do mundo, diz ONU. Matéria publicada em 01/10/2007 às 17h15m. O Globo Online Reuters. Disponivel em: «http://oglobo.globo.com/pais/mat/2007/10/ 01/297954994.asp». Acesso em: 03 mar. 2008.

SHAKESPEARE, William. Hamlet. Tradução: Jean Melville. São Paulo: Martin Claret, 2003.

SILVA NETO, Manoel Jorge e. Curso de direito constitucional. $6^{\mathrm{a}}$ edição. Rio de Janeiro: Lúmen Júris, 2007.

. Direito constitucional econômico. $1^{\mathrm{a}}$ ed. São Paulo: LTr, 2001.

STRECK, Lenio Luiz. Tribunal do júri - Símbolos e rituais. Porto Alegre: Livraria do Advogado, 2001.

SUZANE VON RICHTHOFEN quer anular julgamento que a condenou a 39 anos de prisão. Matéria publicada em 16/01/2008 às 11h52m. O Globo Online. Disponível em: «http://oglobo.globo.com/

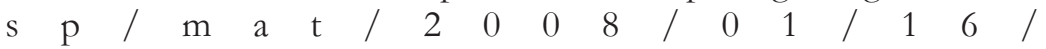
suzane_von_richthofen_quer_anular_julgamento_que_condenou_39_anos_de_prisao328044733.asp». Acesso em: 07 jul.2008.

VIEHWEG, Theodor. Tópica e jurispudência. Uma contribuição à investigação dos fundamentos jurídico-cientificos. Tradução: Kelly Alfen da Silva. Porto Alegre: Safe, 2008.

WARAT, Luís. Mitos e teorias na interpretação da lei. Porto Alegre: Síntese, 1979.

WEBER, Max. Economia e sociedade. Volume I. Brasília: Unb, 2004.

WITTTGENSTEIN, Ludwig. -Tratado lógico filosófico - Investigações filosóficas. $3^{a}$ ed. Tradução M. S. Lourenço. Lisboa: Fundação Calouste Gulbenkian, 2002.

ZAFFARONI, Eugênio Raul. Em busca das penas perdidas. A perda de legitimidade do sistema penal. Tradução: Vânia Romano Pedrosa e Amir Lopez da Conceição. Rio de Janeiro: Revan, 1991.

; BATISTA, Nilo; SLOKAR, Alejandro; ALAGIA, Alejandro. Direito penal brasileiro: primeiro volume. $2^{\mathrm{a}}$ ed. Rio deJaneiro: Revan, 2003. 
ZIPPELIUS, Reinhold. Teoria geral do estado. $3^{\mathrm{a}}$ ed. Tradução de Karin Praefke-Aires Coutinho. Coordenação José Joaquim Gomes Canotilho. Lisboa: Fundação Calouste Gulbenkian, 1997. 